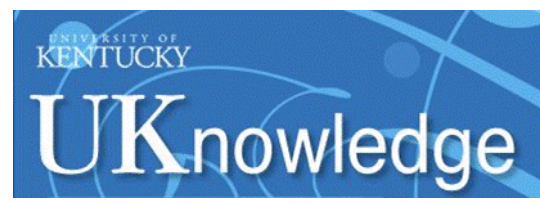

University of Kentucky

UKnowledge

$7-2013$

\title{
Justice John Marshall Harlan: Professor of Law
}

Brian L. Frye

University of Kentucky College of Law, brianlfrye@uky.edu

Josh Blackman

South Texas College of Law

Michael McCloskey

Follow this and additional works at: https://uknowledge.uky.edu/law_facpub

Part of the Legal Education Commons, and the Legal History Commons

Right click to open a feedback form in a new tab to let us know how this document benefits you.

\section{Recommended Citation}

Brian L. Frye, Josh Blackman \& Michael McCloskey, Justice John Marshall Harlan: Professor of Law, 81 Geo. Wash. L. Rev. 1063 (2013).

This Article is brought to you for free and open access by the Law Faculty Publications at UKnowledge. It has been accepted for inclusion in Law Faculty Scholarly Articles by an authorized administrator of UKnowledge. For more information, please contact UKnowledge@lsv.uky.edu. 


\section{Justice John Marshall Harlan: Professor of Law}

\section{Notes/Citation Information}

The George Washington Law Review, Vol. 81, No. 4 (July 2013), 1063-1134 


\title{
Justice John Marshall Harlan: Professor of Law
}

\author{
Josh Blackman,* Brian L. Frye, ${ }^{* *} \&$ Michael McCloskey***
}

\begin{abstract}
From 1889 to 1910, while serving on the United States Supreme Court, the first Justice John Marshall Harlan taught at the Columbian College of Law, which became the George Washington University School of Law. For two decades, he primarily taught working-class evening students in classes as diverse as property, torts, conflicts of law, jurisprudence, domestic relations, commercial law, evidence-and most significantly-constitutional law.

Harlan's lectures on constitutional law would have been lost to history, but for the enterprising initiative-and remarkable note-taking-of one of Harlan's students, George Johannes. During the 1897-98 academic year, George Johannes and a classmate transcribed verbatim the twenty-seven lectures Justice Harlan delivered on constitutional law. In 1955, Johannes sent the transcripts to the second Justice Harlan. The papers were ultimately deposited in the Library of Congress. Though much attention has been given to the life and jurisprudence of Justice Harlan, his lectures have been largely ignored.

Harlan's lectures are a treasure trove of insights into his jurisprudence, as well as the state of constitutional law at the turn of the 20th century. They provide the unique opportunity to listen in as one of our greatest Justices lectures on the precipice of a constitutional revolution that he helped create. In this article, we use the lectures to paint a picture of who Justice Harlan was, what he believed, how he sought to impart that knowledge to the future lawyers of America, and how he predicted many of the changes in constitutional law that occurred during the 20th century.

This article, published along with the annotated transcript of all twentyseven lectures and written on the centennial of Justice Harlan's death, is a tribute to one of the giants of the law, and his contribution to legal education.
\end{abstract}

* Assistant Professor, South Texas College of Law; President, The Harlan Institute.

** Assistant Professor of Law, University of Kentucky College of Law; J.D., New York University School of Law, 2005; M.F.A., San Francisco Art Institute, 1997; B.A., University of California, Berkeley, 1995. Professor Frye's research on this project was funded in part by the Institute for Humane Studies.

*** J.D., Catholic University of America Columbus School of Law, 2012.

The authors thank Scott Campbell, Jack Chin, Ross Davies, Davison Douglas, and Richard Pascal, as well as research assistants Zach Cato, C.J. Ryan, Cyavash Ahmadi, William Reinken, and Erin Ross. The authors dedicate this article to Justice John Marshall Harlan I.

July 2013 Vol. 81 No. 4 
TABle of Contents

INTRODUCTION .................................. 1065

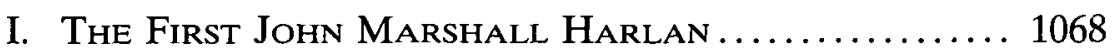

II. Harlan the Professor ........................... 1073

A. Columbian College of Law at the Turn of the

Century ................................... 1073

B. A Justice and a Teacher..................... 1075

1. Harlan's Classes and Schedule............... 1076

2. Relationship with Students ................ 1078

C. Pedagogical Approach ....................... 1080

1. Harlan's Casebook....................... 1080

2. Harlan Did Not Use the Socratic Method ..... 1083

3. Harlan's Constitutional Law Exam ........... 1085

D. The Supreme Court in the Classroom ............. 1087

E. Harlan's Untimely Departure from Columbian

College of Law ............................... 1090

F. Origin of the Lecture Notes .................... 1095

III. Harlan's Jurisprudence ........................ 1096

A. Proto-Originalist ............................ 1097

B. American Exceptionalism and Providence......... 1100

C. American Citizenship and Equal Protection........ 1103

1. A Preview of Wong Kim Ark in Class......... 1103

2. A Recap of Wong Kim Ark in Class ......... 1106

3. Harlan's Enigmatic Approach to Equality ..... 1109

D. Individual Liberty......................... 1111

1. Freedom of Speech .................... 1111

2. Religious Liberty ......................... 1113

3. Economic Liberty...................... 1116

4. Suffrage and Gender Equality ............. 1117

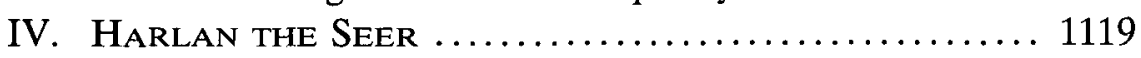

A. Incorporation ............................ 1119

1. Harlan's Prescient Opinions ................ 1120

2. Grand Jury Clause ...................... 1121

3. Right to Jury Trial ..................... 1122

4. Eighth Amendment Prohibition Against Cruel and Unusual Punishment ................... 1123

5. Incorporation in the Twentieth Century ....... 1124

B. The Commerce Clause ........................ 1125

C. The Erie Doctrine and Vertical Comity ........... 1129

D. Separation of Powers ........................ 1131

1. Qualifications of Representatives ............ 1131 
2. Congress Choosing Its Own Rules .......... 1133

3. Bicameralism and Presentment ............. 1133

4. Appointment of Officers................. 1133

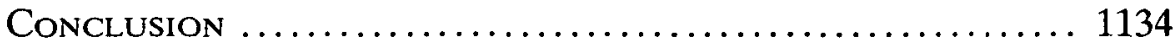

\section{INTRODUCTION}

I have often been astounded to meet with lawyers who have actually never read the Constitution of the United States, although it can be read within the time that is wasted at a street corner some afternoon discussing the last game of baseball or the last prize fight. They may have examined particular clauses, but have never read the entire instrument so as to comprehend in a general way the system of government ordained by it ....

Now, I beg you that this may not be said of any member of this law class that he allow this week to pass without reading the Constitution. Some knowledge of the principles underlying the government under which we live ought to be possessed by every person who owes duties to that government, or upon whom its laws operate, or who depends upon it for protection of his life, liberty, and property. Freedom and free institutions cannot long be entertained by a people who do not understand the nature of the government under which they live. ${ }^{1}$

\section{--Justice John Marshall Harlan I, October 14, 1897.}

From 1889 to 1910, while serving on the United States Supreme Court, the first Justice John Marshall Harlan taught at the Columbian College of Law, which later became The George Washington University School of Law. For two decades, he primarily taught workingclass evening students in classes as diverse as property, torts, conflicts of law, jurisprudence, domestic relations, commercial law, evidenceand most significantly-constitutional law.

Harlan's lectures on constitutional law would have been lost to history but for the enterprising initiative-and remarkable note taking-of one of Harlan's students, George Johannes. During the 1897-1898 academic year, Johannes and a classmate transcribed verbatim the twenty-seven lectures Justice Harlan delivered on constitutional law. In 1955, Johannes sent his copy of the transcripts to the second Justice Harlan, who eventually deposited them in the Library

1 Brian L. Frye, Josh Blackman \& Michael McCloskey, eds., John Marshall Harlan: Lectures on Constitutional Law, 1897-98, 81 Geo. Wash. L. Rev. Arguendo 12, 14-15 (2013) [hereinafter Justice Harlan's Lectures]. 
of Congress. ${ }^{2}$ Harlan's life and jurisprudence have received a great deal of scholarly attention. Yet, tragically, his lectures have been unavailable to the public, and as a result largely ignored. ${ }^{3}$ This Article, along with the first edited and annotated transcription of Harlan's lectures, ${ }^{4}$ will bring those priceless lessons to life.

Harlan's lectures provide a trove of insights into his jurisprudence, as well as the state of constitutional law at the turn of the twentieth century. They offer the unique opportunity to listen in as one of our greatest Justices lectures on the precipice of a constitutional revolution that he helped create. This Article, written on the centennial of Justice Harlan's death, is a tribute to one of the giants of the law, and his contribution to legal education.

In Part I, we survey Justice Harlan's accomplished career. He rose from humble origins in rural Kentucky, served as a Colonel in the Civil War, and was eventually appointed to the United States Supreme Court.

In Part II, we provide a brief description of what law school was like at the turn of the twentieth century. We explain why a Supreme Court Justice would choose to serve as a law professor, and why Harlan accepted such a busy teaching schedule-he taught at night

2 See Letter from George Johannes to John Marshall Harlan (Oct. 21, 1955) (on file with the Library of Congress, Manuscript Division, The John Marshall Harlan Papers, 1810-1971, at A2-1) [hereinafter The Harlan Papers], available at http://www.gwlr.org/wp-content/uploads/ 2013/06/DSC00475.jpg. The George Washington Law Review has made images of The Harlan Papers available on our website to improve reader access to these sources. The collection can be found at http://www.gwlr.org/2013/06/22/harlanpapers/.

Professor Frye purchased a microfilm copy of George Johannes's Japanese paper copy of the transcription of Harlan's lectures from the Library of Congress, Manuscript Division, made a PDF version, and transcribed it verbatim, by hand. See Justice John Marshall Harlan: Lectures on Constitutional Law, 1897-98, INTERNET ARCHIVE, http://archive.org/details/JusticeJohnMarshallHarlanLecturesOnConstitutionalLaw1897-98_26 (last visited June 23, 2013). He then edited and annotated the lectures, with the occasional assistance of several research assistants. The lectures were edited to preserve all of Harlan's words as transcribed, except in cases of clear transcription error. Paragraph breaks and punctuation were added as necessary, in order to reflect the cadence of Harlan's speech. Quotations from the Constitution are set off in separate paragraphs, unless the text requires otherwise. Questions from students are italicized. References are provided for all quotations. Citations are provided for all cases and publications discussed by Harlan. Additional annotations are provided when supplemental information will help the reader better understand Harlan's commentary. See Justice Harlan's Lectures, supra note 1 (containing an edited and annotated transcription of Justice Harlan's lectures).

3 See Tinsley E. Yarbrough, Judicial Enigma: The First Justice Harlan 266 n.43 (1995) (noting a preference for Harlan's judicial opinions over his lectures as a source of insight into his philosophy). But see Linda Przybyszewski, The Republic According to John Marshall Harlan 45 (1999).

4 See Justice Harlan's Lectures, supra note 1. 
and on weekends, much to the chagrin of his wife Malvina, who was not pleased that he would come home so late. We also consider the ethical implications of a sitting Justice teaching constitutional law. Justice Harlan routinely opined on cases before they had been decided, and suggested how he would vote. After a case was decided, if he had dissented, he would often humorously note, "I was one of the minority, and of course I was wrong."

We discuss Harlan's approach to lecturing without notes for two hours each week, unlike his peers at Harvard, who used the Socratic method. He taught the Constitution clause-by-clause, starting with the Preamble and working his way to the recently enacted Fifteenth Amendment. We show that Harlan started working on a previously unknown constitutional law casebook, which he unfortunately never finished. We close by explaining why Harlan stopped teaching when the University suddenly reduced his salary.

In Part III, we use the lectures-as well as contemporary newspaper accounts, personal correspondences, and his judicial opinions-to explain how Harlan's jurisprudence related to the state of constitutional law at the turn of the twentieth century. Harlan's lectures suggest that he was a proto-originalist, whose focus on Anglo-American history and the views of the Framers of the Constitution anticipated the constitutional philosophies of Justice Black, and more recently Justice Scalia. This legal tradition informed Harlan's approach to freedom of speech, religious liberty, economic liberty-as evidenced in his dissent in Lochner v. New York ${ }^{6}$-and gender equality.

Harlan had a deep faith in the "providence" of American culture, and the exceptionalism of its system of laws and liberty-a steadfast belief that pervaded his philosophy. But Harlan's jurisprudence also produced apparent contradictions. Although his powerful dissents in Plessy v. Ferguson ${ }^{7}$ and the Civil Rights Cases $^{8}$ presaged the civil rights revolution of the twentieth century, his vote in United States $v$. Wong Kim Ark ${ }^{9}$-coupled with extended discussions of that case-reveals an inconsistent approach to equality and citizenship.

Finally, in Part IV, we analyze how Harlan augured the future of constitutional law. Harlan's views were decades ahead of the Court's jurisprudence. He saw what was to come in the twentieth century

5 See, e.g., id. at 342 (Lecture No. 27, May 7, 1898).

6 Lochner v. New York, 198 U.S. 45 (1905).

7 Plessy v. Ferguson, 163 U.S. 537 (1896).

8 The Civil Rights Cases, 109 U.S. 3 (1883).

9 United States v. Wong Kim Ark, 169 U.S. 649 (1898). 
with respect to the incorporation doctrine, Congress's powers under the Commerce Clause, the Erie doctrine and vertical comity, as well as separation of powers. Such thoughts were mere glimmers in the eyes of nineteenth century jurists, but were on the forefront of Justice Harlan's mind. Harlan's Constitution-as explained in his remarkably detailed lectures-anticipated much of the Constitution as we know it today.

In this Article, we use Harlan's lectures to help explain who Justice Harlan was, what he believed, how he sought to impart that knowledge to the future lawyers of America, and how he predicted many of the changes in constitutional law that occurred during the twentieth century.

\section{The First John Marshall Harlan}

John Marshall Harlan was born in Boyle County, Kentucky on June $1,1833 .{ }^{10}$ His father, James Harlan, was a lawyer and prominent Whig politician. ${ }^{11}$ After graduating from Centre College in 1850, and Transylvania Law School in 1853, Harlan joined his father's law practice in Frankfort, Kentucky, and became active in Whig politics. ${ }^{12}$ Harlan's evolving position on slavery and his ascension in Kentucky Republican politics paved the way for an unlikely path to the United States Supreme Court.

The Whig Party was formed in the early 1830s to oppose Jacksonian democracy. ${ }^{13}$ It was the unofficial heir of the Federalist Party, and its platform emphasized tariffs and internal improvements. ${ }^{14}$ It elected two Presidents, William Henry Harrison and Zachary Taylor, but its leader was Henry Clay, a close friend of James Harlan's. ${ }^{15}$ Among many other things, Clay drafted the Compromise of 1850 , which defused tensions over slavery and delayed secession and civil war. ${ }^{16}$

10 William E. Read \& William C. Berman, Papers of the First Justice Harlan at the University of Louisville, 11 AM. J. LegAL Hist. 57, 58 (1967).

11 Id. James Harlan was the United States Representative for the Twenty-fifth District of Kentucky from 1835-1839, the Secretary of State of Kentucky from 1840-1844, a member of the Kentucky House of Representatives in 1845, and the Attorney General of Kentucky from 1850-1863. Harlan, James (1860-1863), Biographical Directory of the U.S. Congress, http://bioguide.congress.gov/scripts/biodisplay.pl?index=H000210 (last visited May 28, 2013).

12 Read \& Berman, supra note 10, at 58-59.

13 See Michael F. Holt, The Rise and Fall of the American Whig Party: JacksoNian Poltrics and the Onset of the Civil War, 1-18 (1999).

14 Id. at 738 .

15 Id. at 1.

$16 I d$. at 554 . 
By 1852 , the Whig Party was disintegrating, mainly over slavery. ${ }^{17}$ Southern Whigs supported slavery and Northern Whigs opposed it, creating an irreconcilable division. ${ }^{18}$ The Whig Party finally dissolved in 1854 when Congress passed the Kansas-Nebraska Act, repealing the Missouri Compromise and opening Kansas to slavery. ${ }^{19}$ Most Northern Whigs joined the new Republican Party, but Southern Whigs were adrift. ${ }^{20}$

Like most Kentucky Whigs, Harlan supported slavery, but opposed secession. ${ }^{21}$ Kentucky was a slave state, and the Harlan family owned about a dozen slaves. ${ }^{22}$ When the Whig Party disappeared, Harlan supported whichever party opposed the Democrats and secession. ${ }^{23}$ In 1855, he joined the American or "Know-Nothing" Party, which opposed immigration and Catholicism. ${ }^{24}$ When its appeal waned, he joined the Opposition Party. ${ }^{25}$

In 1858, Harlan was elected judge of the Franklin County Court, his first elected office. ${ }^{26}$ Later that year, on the Opposition Party ticket, which supported slavery and opposed the Democrats, he ran for Congress, but narrowly lost. ${ }^{27}$ In 1860, Harlan switched affiliations again and joined the Constitutional Union Party, which was neutral on slavery and opposed secession, and campaigned for its unsuccessful presidential nominee. ${ }^{28}$

As the Civil War began in 1861, Kentucky was torn between North and South. For example, Senator Powell supported the Union, and Senator Breckinridge quit to join the Confederacy. ${ }^{29}$ While the legislature was mostly pro-Union, Governor Magoffin favored the Confederacy and refused President Lincoln's call for volunteers. ${ }^{30}$ As a captain of the Unionist Home Guards, Harlan opposed the seces-

17 See id. at $726-64$.

18 Id.

19 Kansas-Nebraska Act, ch. 59, 10 Stat. 277 (1854).

20 Holr, supra note 13 , at 916.

21 G. Edward White, John Marshall Harlan I: The Precursor, 19 AM. J. LEGAL Hist. 1, 6 (1975).

22 Przybyszewski, supra note 3, at 20.

23 Id. at 34.

24 Frank B. Latham, The Great Dissenter: John Marshall Harlan 1833-1911, at 10-11 (1970).

25 Id. at 15.

26 Id.

27 Id. at $15-17$.

28 Id. at $17-18$.

29 Id. at $20-22$.

30 Id. at 20-21. 
sionist Southern Rights State Guards by delivering speeches and distributing guns to Unionists. ${ }^{31}$

When the Confederate Army occupied Kentucky in August 1861, the legislature declared itself for the Union, but public sentiment was still split between North and South. ${ }^{32}$ Harlan responded to the occupation by raising a Union regiment, the Tenth Kentucky Infantry. ${ }^{33}$ $\mathrm{He}$ was commissioned as a Colonel, and led his regiment honorably and effectively. ${ }^{34}$ When Harlan's father died in 1863, he resigned his commission and returned to Frankfort to run the family law office. ${ }^{35}$ Later that year, Harlan joined the Union Party and was elected Attorney General of Kentucky. ${ }^{36}$ While Harlan supported the Union, he denounced the suspension of the writ of habeas corpus and the Emancipation Proclamation. ${ }^{37}$ In 1864, he even campaigned for George McClellan, the Democratic presidential candidate. ${ }^{38}$

Initially, Harlan opposed the Reconstruction Amendments because he believed that they infringed on states' rights and would "destroy our kind of government." 39 In 1865 , he joined the Conservative Union Party, which opposed the Reconstruction Amendments. ${ }^{40}$ Then in 1867, he helped form the Conservative Union Democratic Party, an abortive attempt to court Democrats. ${ }^{41}$

But in 1868, Harlan changed his mind and joined the Republican Party. ${ }^{42} \mathrm{He}$ campaigned for Ulysses S. Grant, the Republican presidential candidate, ${ }^{43}$ and supported the Reconstruction Amendments, calling slavery "the most perfect despotism that ever existed on this earth." 44 Accused of opportunism, he responded, "Let it be said that I am right rather than consistent." 45 Harlan's decision to become a Republican was probably motivated by both political and moral factors. ${ }^{46}$

31 LAtham, supra note 24, at 22-23; Przybyszewsk1, supra note 3, at 35.

32 LATHAM, supra note 24, at 20.

33 Id. at 27.

34 Id. at $27-30$.

35 Read \& Berman, supra note 10 , at 59.

36 Id.

37 LATHAM, supra note 24 , at $38-39$.

$38 \mathrm{Id}$. at 39.

39 Loren P. Beth, John Marshall Harlan: The Last Whig Justice 75 (1992) (quoting Letter from John Marshall Harlan to John W. Combs (June 1, 1865)).

40 Przybyszewski, supra note 3 , at 38.

41 Id.

42 Id. at 39.

43 LATHAM, supra note 24, at 58 .

44 Przybyszewski, supra note 3 , at 41.

45 Id.

46 See Charles Thompson, Plessy v. Ferguson: Harlan's Great Dissent, Ky. Human., Apr. 
Many years later, Harlan's students applauded when he declaimed, "Out of this [Dred Scott ${ }^{47}$ case] came the Republican party of today. [Applause]."48 Dred Scott "was a sort of special providence to this country," Harlan said, "in that it laid the foundation of a civil war which, terrible as it was, awful as it was in its consequences in the loss of life and money, was in the end a blessing to this country, in that it rid us of the institution of African slavery." 49

Harlan quickly became the leader of the Kentucky Republicans. ${ }^{50}$ He was the Republican candidate for Governor in 1871 and 1875, but lost both elections. ${ }^{51}$ In 1876, Harlan led the Kentucky delegation to the Republican National Convention in Cincinnati, Ohio. ${ }^{52}$ When the convention deadlocked, he delivered Kentucky's votes to Rutherford B. Hayes, who won the nomination. ${ }^{53}$ The Democratic candidate for President was Samuel J. Tilden. ${ }^{54}$ After the election, Hayes and Tilden both claimed victory. ${ }^{55}$ The decision went to an electoral commission, which awarded the election to Hayes. ${ }^{56}$ On March 2, 1877, Congress accepted the commission's findings, and Hayes became the President. ${ }^{57}$

On March 4, 1877, Justice David Davis resigned from the Supreme Court in order to become a Senator. ${ }^{58}$ After some deliberation, Hayes nominated Harlan to fill the empty seat on October 17, 1877.59 There was some opposition to Harlan, primarily from two Senators who were interested in the position for themselves. ${ }^{60}$ On November 29,1877 , however, the Senate unanimously confirmed the ap-

1996, available at http://www.law.louisville.edu/library/collections/harlan/dissent. Compare YARBROUGH, supra note 3, at 66 (arguing that Harlan joined the Republican Party and adopted its platform out of expediency), with BETH, supra note 39, at 75 (arguing that Harlan joined the Republican Party because his private opinions on racial issues were more liberal than his public opinions).

47 Dred Scott v. Sandford, 60 U.S. (19 How.) 393 (1856)

48 Justice Harlan's Lectures, supra note 1, at 40 (Lecture No. 3, Oct. 23, 1897).

49 Id. at 264 (Lecture No. 21, Mar. 19, 1898).

50 BETH, supra note 39 , at 88 .

51 LATHAM, supra note 24 , at $58,66-68$.

52 Id. at 69.

53 Id.

54 Id. at 70.

55 Id.

56 Id.

57 See Justice Harlan's Lectures, supra note 1, at 207 n.350 (Lecture No. 17, Feb. 19, 1898).

58 LATHAM, supra note 24 , at 71.

59 Id.

$60 \mathrm{Id}$. 
pointment, and on December 10, 1877, Harlan was sworn in. ${ }^{61}$ He was only forty-four years old, one of the youngest justices in Supreme Court history. ${ }^{62}$

Harlan served as a Supreme Court Justice from December 10, 1877 until his death on October $14,1911 .{ }^{63} \mathrm{He}$ is the sixth-longestserving Justice. ${ }^{64}$ When Harlan joined the Court, the Justices were obliged to "ride circuit," or sit on a federal circuit court by designation. ${ }^{65}$ Justice Howell Edmunds Jackson was already assigned to the Sixth Circuit Court of Appeals, which included Kentucky, so Harlan was initially assigned to the Seventh Circuit, which included Wisconsin, Illinois, and Indiana. ${ }^{66}$ In 1891, Congress abolished circuit riding, to the great relief of the Justices. ${ }^{67}$ The Justices were still assigned to circuits for special purposes, however, and when Justice Jackson died in 1895, Harlan was reassigned to the Sixth Circuit. ${ }^{68}$ Today, a portrait of Harlan hangs in the Sixth Circuit's library in Louisville, Kentucky.

Harlan loved his job. He was friendly with his colleagues and popular with the public. ${ }^{69}$ Harlan's relationship with his brethren, however, was complicated. While he agreed with Justice Field on civil rights, he disagreed on the scope of federal power. ${ }^{70} \mathrm{He}$ was not close with progressive judges, like Justices Holmes and Brandeis. ${ }^{71} \mathrm{He}$ was also not close with Justice Hughes. ${ }^{72}$ Instead, Harlan cultivated his reputation as a "common man," one of the last "tobacco-spittin' judges." 73 The newspapers celebrated Harlan's opinions and dissents, and often ran photos of him playing golf, drinking bourbon, and talking to coachmen. ${ }^{74}$

Like many Justices, Harlan found his salary inadequate. For example, Chief Justice Waite earned only $\$ 10,500$ a year, and was nearly

\footnotetext{
61 BETH, supra note 39, at 128-29, 133.

62 LATHAM, supra note 24 , at 71 .

63 ld. at $157-58$

64 See Members of the Supreme Court of the United States, Supreme CT., http://www.
} supremecourt.gov/about/members.pdf (last visited May 29, 2013).

65 BETH, supra note 39, at 138.

66 Id.

67 Id. at 164

68 Id. at 162.

69 LATHAM, supra note 24 , at 113-14.

70 See id. at 104-05, 109-11.

71 See Read \& Berman, supra note 10, at 67 (noting there is no existing correspondence between Harlan and Holmes or Brandeis).

72 See id. (noting there is no existing correspondence between the two Justices).

73 LATHAM, supra note 24 , at 114.

74 See, e.g., Harlan Led the Way: Chevy Chase "Old Boys" Beat Columbia Club Golfers, WASH. Post, Apr. 16, 1905, at SP1. 
bankrupt when he died in $1888 . .^{75}$ In the early 1880 s, Harlan considered resigning from the Court. ${ }^{76}$ Instead, like many of his brethren, he supplemented his income by teaching.

\section{Harlan the Professor}

From 1889 to 1910 , Harlan was a professor at the Columbian College of Law, which eventually became The George Washington University Law School. ${ }^{77}$ He primarily taught constitutional law, but also lectured about personal property law, ${ }^{78}$ torts,${ }^{79}$ conflicts of law,${ }^{80}$ jurisprudence of the United States, domestic relations, commercial law, evidence, ${ }^{81}$ and perhaps other subjects. Unfortunately, his students only recorded his constitutional law lectures. ${ }^{82}$ This Section explores what Columbian was like at the turn of the century, what it meant for a Justice to moonlight as a professor, and how Harlan approached pedagogy. It also recounts Harlan's unceremonious departure from the law school after the University reduced his salary.

\section{A. Columbian College of Law at the Turn of the Century}

The George Washington University Law School, known as the Columbian College of Law until 1904, is the oldest law school in the District of Columbia. ${ }^{83}$ President James Monroe chartered Columbian on February 9, 1821, and the trustees elected William Cranch and William Thomas Carroll as the first law professors. ${ }^{84}$ Cranch was a midnight appointee of President Adams to serve on the D.C. Circuit Court, and President Jefferson later elevated him to chief judge. ${ }^{85} \mathrm{He}$

75 Clare Cushman, Courtwatchers: Eyewitness Accounts in Supreme Court HisTORY 221 (2011).

76 BETH, supra note 39 , at 143.

77 Probing the Law School's Past: 1821-1962, AMICUs CuRIAE, May 1962, reprinted at GW \& FogGy BotTom Hist. Encyclopedia (Dec. 21, 2006), http://encyclopedia.gwu.edu/ gwencyclopedia/index.php?title=Probing_the_Law_School\%E2\%80\%99s_Past:_1821-1962.

78 University Notes, WAsH. Post, Jan. 8, 1900, at 12.

79 Id.; Columbian University Notes, WAsh. Post, May 12, 1895, at 5 (describing how Harlan's students were examined on torts and constitutional law in separate exams for the first time in 1895).

80 Lectures at School of Diplomacy, WAsH. PosT, Nov. 11, 1900, at 16.

81 Columbian University Annual Meeting (June 15, 1891) (on file with the Library of Congress, The Harlan Papers, supra note 2, at A2-161), available at http://www.gwlr.org/wp-content/ uploads/2013/06/DSC00433.jpg.

82 See generally Justice Harlan's Lectures, supra note 1.

83 Probing the Law School's Past, supra note 77.

84 Id.

85 Theodore Voorhees, The District of Columbia Courts: A Judicial Anomaly, 29 CATH. U. L. REV. 917, 920 (1980). 
is best known for serving as a reporter for the United States Supreme Court, ${ }^{86}$ recording for posterity famous cases such as Marbury $v$. Madison. ${ }^{87}$ Carroll was the clerk of the United States Supreme Court from 1827 to 1863.88 Due to a lack of funds, the first incarnation of Columbian College of Law folded; however, the school was eventually reopened in $1865 .^{89}$

Nineteenth century law schools were very different from law schools today. At Columbian, for example, a law degree only required two years of study. ${ }^{90}$ Tuition for one year was $\$ 80^{91}$-approximately $\$ 2,000$ in 2010 dollars. ${ }^{92}$ Prepaying for both years cost only $\$ 150 .{ }^{93}$ Initially, Columbian accepted anyone who enrolled, regardless of his prior qualifications. ${ }^{94}$ Beginning in 1899, it required all students to have "an education equivalent to a high school course."95 The Association of American Law Schools was founded in 1900, with the Columbian College of Law as one of its charter members. ${ }^{96}$ The Law School permitted women to enroll in 1911, and Marion Clark became the first female graduate of the school in $1916 .{ }^{97}$

Amazingly, the faculty of the Columbian College of Law included three Justices of the Supreme Court: Justices Harlan, Strong, and Brewer. ${ }^{98}$ Justice William Strong, who retired from the Court in 1880, taught classes in constitutional jurisprudence from 1881-1888.99 From 1890-1908, Justice David Josiah Brewer taught corporations ${ }^{100}$ and international law, ${ }^{101}$ and possibly other subjects. The University constructed the Harlan-Brewer House on the northeast corner of 20th

86 Probing the Law School's Past, supra note 77.

87 Marbury v. Madison, 5 U.S. (1 Cranch) 137 (1803).

88 G. Edward White, The Marshall Court and Cultural Change, 1815-35, in 3 The Oliver Wendell Holmes Devise: History of the Supreme Court of the United States 384-85 n.2 (Paul A. Freund \& Stanley N. Katz eds., 1988).

89 Probing the Law School's Past, supra note 77.

90 Id.

91 Id.

92 See Robert C. Sahr, Consumer Price Index (CPI) Conversion Factors 1774 to Estimated 2022 to CONVERT to Dollars of 2010 (2012), available at http://oregonstate.edu/ cla/polisci/sites/default/files/faculty_files/sahr/cv2010.pdf.

93 Probing the Law School's Past, supra note 77.

94 Id.

95 Id.

96 Id.

97 See id.; Women of GW Law, L. Ass'N FOR WOMEN, http://docs.law.gwu.edu/stdg/lawwomen/womenofgwlaw.htm (last visited May 29, 2013).

98 Probing the Law School's Past, supra note 77.

99 Id.

$100 \mathrm{Id}$.

101 Lectures at School of Diplomacy, supra note 80. 
and $\mathrm{H}$ Streets N.W. to honor two of its most prominent professors, ${ }^{102}$ though this building is no longer in existence. Columbian also drew other high profile faculty members, such as Professor William Maury. ${ }^{103}$ Maury was appointed Assistant Attorney General of the United States by President Harrison in 1889, and was "one of the most loved professors of the school." 104

\section{B. A Justice and a Teacher}

Today, it is common for most Supreme Court Justices to guest lecture in law school classes and to teach brief study abroad courses during the Supreme Court's summer recess. ${ }^{105}$ Justice Harlan, however, was a regular member of Columbian's faculty and taught a full course load while the Supreme Court was in session. ${ }^{106}$ Furthermore, as a full-time member of the faculty, Harlan taught at inconvenient times-evenings and weekends, ${ }^{107}$ for he was otherwise occupied during the week. And he had to teach classes other than constitutional law that were less than glamorous.

Harlan's teaching style reflected his conception of constitutional law. While his counterparts at Harvard had begun to adopt Langdell's Socratic method of lecturing, ${ }^{108}$ Harlan simply delivered a lecture, and took occasional questions from his students. ${ }^{109}$ Interestingly, he lectured from memory, and did not even use notes: "Exactly how much of the subject I covered I do not remember, as I talk to you without notes, and if I should, in what I am going to say, cover somewhat the same ground, why it will not hurt you to hear it again." 110

Oddly, no one objected to the idea of a Justice teaching constitutional law. Nor did anyone appear to object to Harlan opining on undecided cases. In his lectures, Harlan often remarked that the Su-

102 Probing the Law School's Past, supra note 77.

103 Id.

104 Id.

105 See, e.g., Press Release, S Tex. Coll. of Law, South Texas Students Learn from U.S. Supreme Court Chief Justice John Roberts, available at http://stcl.edu/hottopics/stcl_students_ learn_from_justice_john_roberts.html.

106 See, e.g., Justice Harlan's Lectures, supra note 1, at 126-34 (Lecture No. 11, Jan. 8, 1898).

107 Id. at 242 (Lecture No. 19, Mar. 5, 1898) ("I will complete what I have to say about the judicial power of the Constitution next Saturday night ...."); see also Przybyszewski, supra note 3 , at 46 .

108 See generally W. Burlette Carter, Reconstructing Langdell, 32 GA. L. Rev. 1 (1997).

109 See generally Justice Harlan's Lectures, supra note 1.

110 Justice Harlan's Lectures, supra note 1, at 126 (Lecture No. 11, Jan. 8, 1898). 
preme Court was considering an issue, and explained his own thoughts on the proper outcome of the case. ${ }^{111}$

\section{Harlan's Classes and Schedule}

Due to his duties at the Court, Harlan could only teach on evenings and weekends. His students were mostly working-class men, many of whom were government clerks like Johannes, trying to obtain a law degree at night. ${ }^{112}$ Apparently, Harlan's schedule varied. For example, in 1895, he taught Torts on Monday evenings at seven o'clock. ${ }^{113}$ A 1902 Boston Globe article, which relayed the humorous story of how Harlan broke up a fight after class, suggests he was still teaching a "regular lecture [in] the evening," 114 even though the evening program may have been eliminated at that point. ${ }^{115}$ Harlan bucked a moving trend towards eliminating the evening classes. ${ }^{116}$

While Harlan professed to love teaching, it appears that he taught primarily in order to supplement his income. "Harlan's annual salary was $\$ 10,000$ when he joined the Court, increased to $\$ 12,500$ in 1903 , and was $\$ 14,500$ in 1911 , the year of his death."117 When Columbian hired Harlan as "Professor of the Federal Jurisprudence of the United States, of Domestic Relations, of Commercial Law, and of the Law of Evidence" in 1891, it offered a salary of $\$ 2,000$ a year-twenty percent of his annual income. ${ }^{118}$ And Harlan was not alone. Justice Brewer who was willing to accept a lower fee, taught corporations for $\$ 500$ a year. ${ }^{119}$

Harlan explained to his students how difficult it was to live in Washington, D.C. on a government salary:

Well, why should not a man be paid because he is a servant of the public? We compensate our Senators and Representatives in a moderate degree, in order that they may give themselves to the service of the country, and if that were not

111 Id.

112 PrZYBYSZEwSKi, supra note 3 , at 46.

113 Columbian University Notes, WASH. Post, Feb. 10, 1895, at 15.

114 Prevented a Class Fight, Bos. DaIly Globe, Oct. 24, 1902, at 5.

115 PRZYBYSZEWSKI, supra note 3, at 46 ("When George Washington University joined the Association of American Law Schools in 1902, night classes were ended.").

116 Id. ("By teaching working men at night, Harlan was also at odds with the efforts to do away with night schools on the grounds that their admission standards and requirements were too low.").

117 Malvina Shanklin Harlan, Some Memories of a Long Life, 1854-1911, at 260 n.118 (2003).

118 Columbian University Annual Meeting, supra note 81.

119 Id. 
the rule, it would have occurred in the history of our country that we would have lost the services of some of the greatest men that have figured in all our history. And we pay them little enough. No Senator, except upon the utmost economy, can get along in the city of Washington, make ends meet at the close of each year, upon the salary he gets. No Representative can do it, or very few can.

Well, you ask, if that is so, why do they remain in public life? I cannot tell, except from the feeling of the ambition that is planted in the breast of every man to live after he is dead and gone in the memory of his fellow citizens. I can understand why a man may be willing to give his whole life, and lead a life of poverty and self-denial, if by so doing he can make a great name in his country.

That is true of our profession. There are very few lawyers that have the gift of money making. There are very few lawyers that lay up large estates, and when you find the lawyer who loves money better than he does the practice of his profession, it is absolutely certain that he never makes a great lawyer or a good lawyer. ${ }^{120}$

Harlan's wife Malvina lamented his paltry salary and inconvenient schedule, which required a late commute to his home in Rockville, Maryland:

Thus, for two years my husband became a "Commuter," taking the tiresome thirty-two miles ride in and out, six times each week. Three times a week, however, he remained in town until the mid-evening train, in order to teach his class at the Law School of what is now the George Washington University-a position which, in spite of the arduous work it entailed, he felt compelled to retain, as his judicial salary was not large enough to provide for the education and maintenance of our surviving five children and our granddaughter. ${ }^{121}$

Harlan even considered resigning from the Supreme Court and accepting a position as a lecturer at the University of Chicago, at a salary of $\$ 25,000$ per year: ${ }^{122}$

I should be greatly tempted to surrender my present position and accept his offer. I could imagine nothing more agreeable

120 Justice Harlan's Lectures, supra note 1, at 86 (Lecture No. 7, Nov. 20, 1897).

121 HARLAN, supra note 117, at 117 (citations omitted).

122 Read \& Berman, supra note 10, at 65 ("To Willson, he [Harlan] indicates that he would be tempted to accept if Rockefeller offered him $\$ 25,000$ per year to lecture at the University of Chicago, as Rockefeller had offered to Harrison."). 
to me than to spend the balance of my life in that sort of work. I think I may say without egotism, that I can perform that work better than any I have ever undertaken. ${ }^{123}$

Ultimately, he declined the offer, remained on the Supreme Court, and continued teaching at The George Washington University Law School until 1910. ${ }^{124}$

\section{Relationship with Students}

Harlan was a remarkably popular professor. According to one newspaper account:

Promptly at 7 o'clock Justice Harlan enters and takes his seat on the platform. His appearance is greeted with cheer after cheer from the students and visitors. He must . . . wait a minute or two before he can make his voice heard above the clamor of approval. Then his great form, clad frequently in evening dress, rises amid the hisses of the boys for silence, and by the time he has uttered his familiar greeting- "young gentlemen of the law class"-the dropping of a pin can almost be heard, so still is the room and close the attention paid him, which continues to the end of the lecture, though interrupted with popular applause, or laughter, at the frequent fine points scored, and witty thrusts. ${ }^{125}$

As one of Harlan's students recalled, "[t]he spontaneity of the applause that frequently marked the beginning and close of his sessions, was sufficient evidence of the appreciation the members had of him." 126

Even outside the classroom, Justice Harlan was an imposing figure on campus. A large and powerful man, Harlan was not just a teacher; he was a mentor. In 1902, at the ripe age of sixty-nine, he "interfered and prevented a class fight between the freshmen and sophomores . . . . [T] he eminent jurist . . reached over the heads of the assaulting party, and seizing the leader of the forces by the collar, dragged him from the fight." $127 \mathrm{He}$ sought to inspire his students to greatness in the legal profession. Harlan deeply respected the legal

123 Id. at 65 n.30 (quoting Letter from John Marshall Harlan to Augustus Willson (Mar. 13, 1893))

124 BETH, supra note 39, at 186.

125 Przybyszewski, supra note 3, at 44-45 (citing Little Rock Saturday Bee, Apr.16, 1895 (on file with The John Marshall Harlan Collection, Univ. of Louisville)).

126 BETH, supra note 39, at 186 (quoting Letter from Almon C. Kellogg to Richard D. Harlan (May 27, 1930) (on file with The John Marshall Harlan Collection, Univ. of Louisville)).

127 Prevented a Class Fight, supra note 114. 
profession, and remarked at a banquet at Columbian Law School, "[t]he mainstay of the country at critical moments was [the legal] profession," noting that if the legislature "were composed of farmers, merchants, and ministers, and lawyers left out, there would be produced statutes which no man could understand."128

Harlan believed in shared interests and the power of collective action. He often spoke directly to his students, referring to them as "you." 129 Similarly, he referred to America as "we," assuming that all Americans had similar interests. ${ }^{130}$ On one occasion, Harlan wrote to the President of George Washington University:

One of the pleasantest features of my labors was the receipt of letters from students, in every section, who attended my lectures and who said that the time passed with me was both delightful and instructive. I was buoyed up with the thought that my lectures had much to do with spreading safe and sound thoughts about our National Government and the Constitution under which it was organized. ${ }^{131}$

Harlan cultivated a warmly paternalistic relationship with his students. He urged them to read the Constitution and learn about American history. He counseled against radical politics and jingoism, criticizing secessionists and progressives alike. For example, he closed one lecture by advising his students not to jump to conclusions about the USS Maine, which had just sunk in Havana Harbor. Referencing the event obliquely as "the great calamity that has occurred in the waters nearby," Harlan told his students "not to lose their heads," but rather to "keep cool, and not to pass judgments upon grave questions when you have not the facts before you." $132 \mathrm{He}$ admonished his class that the legal profession teaches us to "wait until the case is presented before you to reach a final conclusion." 133 Harlan explained that he hoped the sinking was not "an act of treachery and duplicity," but

128 Columbian Law School Banquet, WAsH. Post, Apr. 24, 1897, at 9.

129 See, e.g., Justice Harlan's Lectures, supra note 1, at 81 (Lecture No. 7, Nov. 20, 1897); see also PrZYByszewski, supra note 3, at 61-62.

130 See, e.g., Justice Harlan's Lectures, supra note 1, at 14 (Lecture No. 1, Oct. 14, 1897); see also PRZYBYsZewski, supra note 3, at 61-62 ("He used . . . the second-person pronoun--'you' instead of 'one'-in order to involve his students . . . . He often used the pronoun 'we' to include his students in [the] belief [that the U.S. Constitution was superior to any other plan of government that had ever existed].").

131 BETH, supra note 39, at 187 (quoting Letter from John Marshall Harlan to Walter C. Clephane (Aug. 4, 1910) (on file with the Library of Congress, The Harlan Papers, supra note 2)).

132 Justice Harlan's Lectures, supra note 1, at 213 (Lecture No. 17, Feb. 19, 1898).

$133 \mathrm{Id}$. 
rather an accident. ${ }^{134}$ And he emphasized national unity, proclaiming that if it was not an accident, "we will not hear any more of North, South, East, or West in this country, but we will only hear of Americans."135 After speeches like this, his students often responded with a standing ovation, reflecting their respect and admiration for their beloved professor. ${ }^{136}$

\section{Pedagogical Approach}

Pedagogically, Harlan's lectures would be foreign to most modern day law students. At the time, law professors were gradually adopting the Socratic method of teaching advocated by Langdell. ${ }^{137}$ However, Harlan resisted this trend and continued to use a more traditional lecture format. ${ }^{138}$ Harlan lectured for two hours straight, taking occasional questions from his students. ${ }^{139}$ Remarkably, he did not use any notes, lecturing entirely from memory, including case names and even citations. ${ }^{140}$

Harlan saw the Constitution as an expression of American values and a source of civic virtue, and used his lectures to cultivate those values. He saw his students as future leaders, and reminded them of their responsibility to the commonwealth. ${ }^{141}$ In particular, he emphasized the critical role that lawyers have played in America's history. ${ }^{142}$

\section{Harlan's Casebook}

At first, Harlan used Justice Joseph Story's Commentaries on the Constitution of the United States as his textbook, and borrowed much of Story's analysis of the Constitution. ${ }^{143}$ However, by 1907, he was using Emilin McClain's Selections of Cases and Constitutional Law

134 Id.

135 Id.

136 Przybyszewski, supra note 3 , at 45.

137 Id. at 46.

138 Id. ("Harlan appears naive in the eyes of many legal scholars . . . Harlan did not even have the saving grace of using the new case method of teaching begun at Harvard Law School under Christopher C. Langdell in 1870, a method that still reigns in law schools today.").

139 See generally id. at 45-47, 60-61.

140 See, e.g., Justice Harlan's Lectures, supra note 1, at 126 (Lecture No. 11, Jan. 8, 1898).

141 See, e.g., id. at 85-86 (Lecture 7, Nov. 20, 1897) (commending public officials for sacrificing personal wealth in order to serve as senators, representatives, and lawyers).

142 See, e.g., id at 23 (Lecture No. 2, Oct. 21, 1897) (stating that "it is true in the history of all the Anglo-Saxon race, and many other races, that it is the lawyer that has stepped forward and has put himself in the way of arbitrary power to defend the rights of man.").

143 PRZYBYSZEWSKI, supra note 3 , at 60 . 
and Thomas Cooley's General Principles of Constitutional Law in the United States of America. ${ }^{144}$

In a 1910 letter, Harlan stated that he was working on a casebook consisting of "select cases on constitutional law." 145 While there is no evidence that Harlan ever completed his casebook, his personal papers suggest that he made some progress on it. For example, he made a list of certain Supreme Court cases in which he had participated that touched on issues of constitutional law. ${ }^{146} \mathrm{He}$ made notations on several of those cases, wrote one-paragraph summaries, and marked up the text of the Supreme Court's opinions. ${ }^{147}$

One such case was Dorr v. United States. ${ }^{148}$ Dorr, a follow-up to the Insular Cases, considered whether "trial by jury is a necessary incident of judicial procedure in the Philippine Islands, where demand for trial by that method has been made by the accused and denied by the courts established in the islands." 149 The Court upheld the trial without a jury. ${ }^{150}$ Harlan dissented, adhering to the view that the protections of the Bill of Rights were fundamental and protected the right to trial by jury. ${ }^{151}$ This was a precursor to what we now know as the incorporation doctrine.

Harlan wrote a one-paragraph summary of Dorr. ${ }^{152}$ Below the summary Harlan scribbled "c book," presumably referring to his intended casebook. ${ }^{153}$ Harlan appended to his typed summary of Dorr a

144 George Washington Univ., The George Washington University Bulletin 169 (1907).

145 Przybyszewski, supra note 3, at 220 n.10 (citing Letter from John Marshall Harlan to Walter C. Clephane (Aug. 4, 1910) (on file with the Library of Congress, The Harlan Papers)).

146 See generally Case Summary of Dorr v. United States (on file with the Library of Congress, The Harlan Papers, supra note 2, at A2-31), available at http://www.gwlr.org/wp-content uploads/2013/06/DSC00302.jpg (paragraph summary of Dorr v. United States, 195 U.S. 138 (1904)); Annotated Copy of Dorr v. United States (on file with the Library of Congress, The Harlan Papers, supra note 2, at A2-37), available at http://www.gwlr.org/wp-content/uploads/ 2013/06/DSC00308.jpg (handwritten notation on a copy of Dorr, 195 U.S. 138).

147 Id

148 Dorr v. United States, 195 U.S. 138 (1904).

$149 I d$. at 139.

150 Id. at 153.

$151 I d$. at 154. (Harlan, J., dissenting) ("I do not believe now any more than I did when Hawaii v. Mankichi, 190 U.S. 197, was decided, that the provisions of the Federal Constitution as to grand and petit juries relate to mere methods of procedure and are not fundamental in their nature. In my opinion, guaranties for the protection of life, liberty and property, as embodied in the Constitution, are for the benefit of all, of whatever race or nativity, in the States composing the Union, or in any territory, however acquired, over the inhabitants of which the Government of the United States may exercise the powers conferred upon it by the Constitution.").

152 Case Summary of Dorr v. United States, supra note 146.

$153 \mathrm{Id}$. 
marked-up copy of the case itself. ${ }^{154} \mathrm{He}$ crossed out elements, mostly citations to the Lawyers' Edition and the Supreme Court Reporter. ${ }^{155}$ At the conclusion of Justice Day's majority opinion, Harlan scribbled at the bottom of the page, "The balance of Peckham's [concurring] opinion and all of mine [dissenting]."156 This suggests that he sought to include in the casebook part of Peckham's concurring opinionand to no one's surprise-all of his own dissenting opinion.

Harlan also wrote a one-page summary of Dooley v. United States. ${ }^{157}$ Dooley found unconstitutional a fifteen percent duty imposed on all merchandise imported to Puerto Rico from the United States. ${ }^{158}$ Typewritten at the bottom of the page is "(Get opinion and dissenting opinions)." 159 This sentence was crossed out. ${ }^{160}$ Following the summary, he included an annotated copy of the case. ${ }^{161}$ Harlan repeated this process for several more cases. ${ }^{162}$ All of the cases dealt with the application of laws to territories, including Hawaii and Puerto Rico. This could have been the beginning of Harlan's unpublished casebook.

Imagine a Justice today publishing a casebook with his own opinions! Today, people might consider it improper for Justices to publicly discuss cases they have decided, based on a potential appearance of impropriety. It is unlikely that a current Justice would publish a casebook discussing cases in which he or she participated. But in Harlan's day it was quite normal. For example, Justice Thomas M. Cooley published many treatises touching on cases he had decided,

154 Id

$155 I d$.

156 Annotated Copy of Dorr v. United States, supra note 146.

157 Dooley v. United States, 182 U.S. 222, 235 (1901); Case Summary of Dooley v. United States (on file with the Library of Congress, The Harlan Papers, supra note 2, at A2-40), available at http://www.gwlr.org/wp-content/uploads/2013/06/DSC00311.jpg.

158 Dooley, 182 U.S. at 235.

159 Case Summary of Dooley v. United States, supra note 157.

160 Id.

161 Annotated Copy of Dooley v. United States (on file with the Library of Congress, The Harlan Papers, supra note 2, at A2-41-52), available at http://www.gwlr.org/wp-content/uploads/ 2013/06/DSC00312.jpg.

162 E.g., Case Summary of DeLima v. Bidwell (on file with the Library of Congress, The Harlan Papers, supra note 2, at A2-53), available at http:/www.gwlr.org/wp-content/uploads/ 2013/06/DSC00324.jpg; Case Summary of Downes v. Bidwell (on file with the Library of Congress, The Harlan Papers, supra note 2, at A2-58), available at http://www.gwlr.org/wp-content/ uploads/2013/06/DSC00329.jpg; Case Summary of Hawaii v. Mankichi (on file with the Library of Congress, The Harlan Papers, supra note 2, at A2-59), available at http://www.gwlr.org/wpcontent/uploads/2013/06/DSC00330.jpg; Annotated Copy of The Diamond Rings Case (on file with the Library of Congress, The Harlan Papers, supra note 2, at A2-54-57), available at http:// www.gwlr.org/wp-content/uploads/2013/06/DSC00325.jpg. 
among others. ${ }^{163}$ Likewise, Justice Story's Commentaries were effectively analyses of cases that he participated in deciding. ${ }^{164}$

\section{Harlan Did Not Use the Socratic Method}

During the 1897-1898 term, Justice Harlan taught twenty-seven classes on constitutional law, every Saturday for two hours. ${ }^{165}$ Unlike the Langdellians at Harvard, Justice Harlan did not use the Socratic method of teaching; rather, he lectured. ${ }^{166} \mathrm{He}$ began with a discussion of the Magna Carta, Anglo-American legal history, the Declaration of Independence, and the legal philosophies of the American Revolution. ${ }^{167} \mathrm{He}$ then proceeded through the Constitution article by article, clause by clause, and amendment by amendment, following the model of Justice Story's Commentaries. ${ }^{168}$ Harlan rarely posed questions to his students, and they seldom asked questions. Occasionally, he would engage in a colloquy with a student, perhaps experimenting with the Socratic approach. ${ }^{169}$

Unsurprisingly, Harlan started his journey through the Constitution with a discussion of the Preamble and its purpose:

The purpose of the preamble to a statute is to state the evils which it was proposed to remedy by the statute, as well as the object for which the statute was enacted. So, the preamble to the Constitution states what was the evil pre-existing and what was the remedy to be applied....

That preamble does not contain any grant of power. ${ }^{170}$

As he began his discussion of each new article or section, he summarized its general purpose. Article I: "Congress cannot organize any other body in this country and invest it with legislative power, because

163 See, e.g., 1 Thomas M. Cooley \& Victor H. Lane, A Treatise on the Constitu. tional Limitations Which Rest upon the Legislative Power of the States of the AMERICAN UNION 204 (7th ed. 1903) (discussing a Supreme Court of Michigan decision, written by Cooley, as to the importance of the title of a statute).

164 See, e.g., James McClellan, Joseph Story and the American Constitution 172-73 (1971) (citing 1 Joseph Story, Commentaries on the Constitution of the UNITED STATES $\$ 158$ n.2 (Boston, Hilliard, Gray \& Co. 1833)) (describing a case in which Story "vigorously" defended his original position twenty years later).

165 See generally Justice Harlan's Lectures, supra note 1 (containing the twenty-seven lectures delivered during the 1897-1898 term).

166 See supra note 138 and accompanying text.

167 See Justice Harlan's Lectures, supra note 1, at 22-30 (Lecture No. 2, Oct. 21, 1897).

168 PRZYByszewski, supra note 3, at 60.

169 See, e.g., Justice Harlan's Lectures, supra note 1, at 288-90 (Lecture No. 23, Apr. 2, 1898).

170 Id. at 43 (Lecture No. 4, Oct. 30, 1897). 
this says all legislative power herein granted shall be vested in a Congress of the United States, and that shall consist of a Senate and a House of Representatives."171 Article II: "The President does not make a law. He has no more power to make a law than you have, but he has power to execute it, to see that it is executed, not perhaps in every way, but in the way prescribed by law." 172 Article III: "The judicial power means the power which is called into existence to determine disputes between individuals or between individuals and corporations, sometimes between states, and that power is vital to the existence of society." 173 And so he proceeded, through the Bill of Rights, the amendments, all the way up to the most recently enacted Fifteenth Amendment. ${ }^{174}$

Despite lecturing without any notes, relying entirely on his memory, Harlan's lectures were very well organized and easy to understand. ${ }^{175}$ Moreover, he often discussed particular cases in minute detail, recounting their facts and even providing a citation. ${ }^{176}$ More often than not, Harlan's examples were cases in which he had written the opinion or dissented. ${ }^{177}$ In addition, many of Harlan's hypotheticals reflected the facts of cases he had decided. ${ }^{178}$

Harlan frequently posed rhetorical questions in order to explore the meaning of a clause. For example, when discussing the President's powers under Article II, he made the following comments:

$[\mathrm{H}] \mathrm{e}$ shall take care that the laws of the United States are faithfully executed.

Take care how? According to his arbitrary will, to do whatever in his judgment may be necessary to that end? No, because when he is executing the laws of the United States, he must understand there are certain things he cannot do. ${ }^{179}$

While Harlan's students rarely asked questions, when they did, he always answered them as fully and graciously as he could. If a stu-

171 Id. at 45.

172 Id. at $45-46$.

173 Id. at 46.

174 See generally id.

175 See generally id.

176 See, e.g., id. at 79-81 (Lecture No. 7, Nov. 20, 1897) (describing a case Harlan decided while riding circuit).

177 See, e.g., id.

178 See, e.g., id. at 89-90 (Lecture No. 8, Dec. 4, 1897) (using the facts of an actual U.S. Supreme Court case as a hypothetical).

179 Id. at 230 (Lecture No. 19, Mar. 5, 1898). 
dent's question was unclear, Harlan would help refine or recast it. ${ }^{180}$ Harlan's attentiveness to his students' questions reflected his humility. When he did not know the answer to a question, he would admit his ignorance, and return the following class with a complete answer. ${ }^{181}$

\section{Harlan's Constitutional Law Exam}

No law school course would be complete without an exam. Justice Harlan's examinations were rather straightforward, and many of the questions were taken directly from his lectures. One question asks "[w] hat does interstate commerce embrace," whether a state court can "declare an act of Congress void as in violation of the Constitution of the United States," and what is meant by "liberty" and "due process of law" in the Constitution. ${ }^{182}$ In another exam, focusing on Article II, he asks how the President is elected and what is the scope of the President's powers. ${ }^{183}$ In a question on the Courts, he asks his students about how the judicial power is vested in the Constitution, and what is the nature of the federal court's jurisdiction. ${ }^{184}$ Answering these questions requires no citation to any case law, though a student would need to have memorized all of the clauses of the Constitution. Many of these questions are exactly the same types of rhetorical questions Harlan posed, and answered, in class. ${ }^{185}$

Harlan also asked very specific questions, including "[w]hat are direct taxes" and "[h]ow are [indirect taxes] to be levied."186 Harlan discussed just this topic in lecture on February 5, 1898:

180 See, e.g., id. at 279 (Lecture No. 22, Mar. 26, 1898) (correcting a student's question about practical nullification of a provision).

181 PRZYBYszewski, supra note 3, at 61 ("One student recalled years later that Harlan once admitted to being unable to answer a question but promised to look it up: 'For one of the greatest judges of the Supreme Court to avoid any degree of evasion, and to tell a class of greenhorns that he was not positive as to the answer of one of their questions, naturally gave the students confidence that anything he told them in the future would be a thing to be relied on.'" (quoting Letter from Almon C. Kellogg to Richard D. Harlan (May 27, 1930) (on file with The John Marshall Harlan Collection, Univ, of Louisville))).

182 Exam May 25 (no year listed) (on file with the Library of Congress, The Harlan Papers, supra note 2, at A2-67), available at http://www.gwlr.org/wp-content/uploads/2013/06/DSC00277. jpg (page 1), http://www.gwlr.org/wp-content/uploads/2013/06/DSC00278.jpg (page 2).

183 Exam (on file with the Library of Congress, The Harlan Papers, supra note 2, at A2-89, 93), available at http://www.gwlr.org/wp-content/uploads/2013/06/DSC00360.jpg.

184 Exam (on file with the Library of Congress, The Harlan Papers, supra note 2, at A2. 97-98), available at http:/www.gwlr.org/wp-content/uploads/2013/06/DSC00368.jpg.

185 See, e.g., Justice Harlan's Lectures, supra note 1, at 310 (Lecture No. 24, Apr. 16, 1898).

186 Exam (on file with the Library of Congress, The Harlan Papers, supra note 2, at A2104-105), available at http://www.gwlr.org/wp-content/uploads/2013/06/DSC00375.jpg. 
Now, if you want to find a discussion on the subject of what are direct taxes, if you will look to the case of Pollock against the Farmers' Loan and Trust Company, at the close of 157 United States, and the same case in 158 United States, you will find there all that the Supreme Court of the United States, and each of its members, had occasion to say awhile back upon an income tax. ${ }^{187}$

Of course, one of those members was Justice Harlan, who dissented in Pollock v. Farmers' Loan \& Trust Co., 188 a 5-4 decision in which the Supreme Court held that the Income Tax Act of 1894 imposed unapportioned direct taxes, and was unconstitutional. ${ }^{189}$ In dissent, Justice Harlan lamented that the Court "denie[d] to the general government a power which is, or may become, vital to the very existence and preservation of the Union." 190 Hopefully Harlan's students paid attention in class, and knew how their instructor viewed this issue. However, any answer to this question would soon become obsolete, as the Sixteenth Amendment, ratified in 1913 in response to Pollock, gave Congress the power to impose an income tax. ${ }^{191}$

It is interesting to compare this examination with Professor James Bradley Thayer's constitutional law examination at the Harvard Law School in $1898 .{ }^{192}$ Thayer's examination consisted of ten questions and called for rather lengthy answers: "[ $t]$ hirty pages is a good maximum." 193 Thayer's exam closely resembles a modern constitutional law exam. He asked questions that required students to apply constitutional concepts to novel scenarios, such as "[t]he State of Texas establishes, regulates, and taxes ferries between that State and Mexico and Louisiana. May it lawfully do so? Why?"194 Similarly, he asked whether "[a]n officer of volunteers mustered into the service of the United States" who kills a bystander in Boston can "be punished constitutionally in the local courts" or in the "[f]ederal courts." 195

187 Justice Harlan's Lectures, supra note 1, at 176 (Lecture No. 15, Feb. 5, 1898).

188 Pollock v. Farmers' Loan \& Trust Co., 158 U.S. 601 (1895).

189 Id.

190 Id. at 671 (Harlan, J., dissenting).

191 U.S. Const. amend. XVI.

192 James Bradley Thayer, Constitutional Law, in Harvard University Examinations 37, 37-39 (1989). Thayer's other examinations are available at Harvard Law School: Annual Examinations, 1871-1995, HARV. LiBR., http://oasis.lib.harvard.edu/oasis/deliver/deepLink?_collection=oasis\&uniqueId=law00237 (last visited May 29, 2013).

193 Thayer, supra note 192, at 37 (emphasis omitted).

194 Id. at 38.

195 Id. at 39 . 
By contrast, Harlan's questions hewed closely to the text of the Constitution. Unlike Thayer, Harlan asked questions that had definite answers and did not pose the open-ended questions that are common in modern constitutional law exams. Perhaps the structure of Harlan's exam reflected his formalism. Harlan's approach to the Constitution was textualist or originalist. According to him, all questions of constitutional law could and should be answered by resorting to the text and history of the Constitution.

\section{The Supreme Court in the Classroom}

Justice Harlan frequently infused his lectures with recent developments in the law, including cases he decided on the Supreme Court. He often referred to the Supreme Court as "we": "We have said, that is, the highest tribunal of the country has said . . ."196 More often than not, he discussed cases in which he wrote the opinion. On one occasion, he asked the students to read an opinion and remarked,

I have some little embarrassment in asking you to read the case because I wrote the opinion, but as it is the only case covering the precise ground that we have had in our court, and as it has received the unanimous opinion of the court, I therefore refer you to it. ${ }^{197}$

Harlan was coy about his dissents. According to one student, Justice Harlan "always got a good laugh when he would explain a majority opinion of the Supreme Court and then outline his own sole dissenting opinion ... and after a sufficient pause, add: 'But of course I was wrong." " 198 For example, when discussing Elk v. Wilkins ${ }^{199}$ on March 19, 1898, Harlan also displayed his wit, noting, "I had the misfortune to differ from the Court upon that question, and of course I was wrong." 200

Many of the current justices are considerably less humble, and more certain of the correctness of their position, even when in dissent.

196 Justice Harlan's Lectures, supra note 1, at 118 (Lecture No. 10, Dec. 18, 1897) (emphasis added).

197 Id. at 97 (Lecture No. 8, Dec. 4, 1897).

198 BETH, supra note 39, at 186 (quoting Letter from Almon C. Kellogg to Richard D. Harlan (May 27, 1930) (on file with The John Marshall Harlan Collection, Univ. of Louisville)).

199 Elk v. Wilkins, 112 U.S. 94 (1884), superceded by statute, Indian Citizenship Act of 1924, ch. 233,43 Stat. 253.

200 Justice Harlan's Lectures, supra note 1, at 266 (Lecture No. 21, Mar. 19, 1898); see also $i d$, at 310 (Lecture No. 24, Apr. 16, 1898) ("Now, presumably I am wrong, because I stood alone, and the law must be held otherwise.") (discussing Hurtado v. California, 110 U.S. 516, 538 (1884)). 
Regarding her dissenting view in Berghuis v. Thompkins, ${ }^{201}$ Justice Sotomayor stated, "I do think I was right. I think the [majority was] wrong." 202 In a common refrain about Bush v. Gore, ${ }^{203}$ Justice Scalia simply says, "Get over it." 204 Of his dissenting view in Bush v. Gore, Justice Stevens said, "I don't question the good faith of the people, the justices with whom I disagreed. But I think they were profoundly wrong." 205 This is to say nothing of the so-called "perpetual dissents," where a Justice repeatedly takes the same position in dissent. ${ }^{206}$ Justice Breyer, who refused to accept the Court's landmark ruling in $\mathrm{Ap}$ prendi v. New Jersey, ${ }^{207}$ wrote two years later in Harris v. United States that "I cannot yet accept its rule."208 Likewise, Justices Black and Douglas habitually dissented to every opinion upholding a federal obscenity law, on the ground that they violated the First Amendment. ${ }^{209}$

Given Harlan's tendency to cite himself, even in dissent, it is not surprising that The Great Dissenter did not dwell on his losses. Harlan often used his own opinions to teach various doctrines and subjects of constitutional law. In addition to assigning his own opinion in Field v. Clark, ${ }^{210}$ he taught or recommended many of his own opinions. For example, on January 29, 1898, he lectured on the Migration and Habeas Clauses of Article I, Section 9.211 At the end of the lecture Harlan asked his students to read three cases to supplement what he had already told them ${ }^{212}$ : Ex Parte Royall, ${ }^{213} \mathrm{New}$ York $v$. Eno, ${ }^{214}$ and Robb v. Connolly. ${ }^{215}$ He neglected to mention that he had

201 Berghuis v. Thompkins, 130 S. Ct. 2250, 2266-78 (2010) (Sotomayor, J., dissenting).

202 Felisa Cardona, Stubborn Side Has Helped Justice Prevail, Denv. Post, Aug. 27, 2010, at A1.

203 Bush v. Gore, 531 U.S. 98 (2000).

204 Bill Mears, Scalia Dismisses Talk of Internal Court Rancor, CNN (July 19, 2012, 10:07 AM), http://www.cnn.com/2012/07/19/us/scalia-morgan-interview/index.html.

205 Supreme Court Justice John Paul Stevens Opens Up, CBSNews (Dec. 5, 2010, 9:13 PM), http://www.cbsnews.com/2100-18560_162-7082572.html.

206 Allison Orr Larsen, Essay, Perpetual Dissents, 15 Geo. Mason L. Rev. 447, 451 (2008).

207 Apprendi v. New Jersey, 530 U.S. 466, 555 (2000) (Breyer, J., dissenting).

208 Harris v. United States, 536 U.S. 545, 569 (2002) (Breyer, J., concurring in part and concurring in the judgment). See generally Larsen, supra note 206 (noting Justice Breyer's frequent dissents in Sixth Amendment, sovereign immunity, and Commerce Clause cases).

209 See, e.g., Jacobellis v. Ohio, 378 U.S. 184, 196-97 (1964) (Black, J., joined by Douglas, J., concurring in the judgment) (raising First Amendment concerns, citing three previous concurrences by Justice Black and one dissent and one concurrence by Justice Douglas).

210 Field v. Clark, 143 U.S. 649 (1892); Justice Harlan's Lectures, supra note 1, at 97 (Lecture No. 8, Dec. 4, 1897).

211 Justice Harlan's Lectures, supra note 1, at 163-73 (Lecture No. 14, Jan. 29, 1898).

212 Id. at 173.

213 Ex Parte Royall, 117 U.S. 241 (1886) (Harlan, J.).

214 New York v. Eno, 155 U.S. 89 (1894) (Harlan, J.). 
written all three opinions. ${ }^{216}$ Harlan frequently discussed several cases he participated in deciding, including United States $v$. Ballin, ${ }^{217}$ In re Medley ${ }^{218}$ (a case dealing with the Ex Post Facto Clause) and In re Neagle. $^{219}$

Justice Harlan sometimes took advantage of opportunities to relate personal anecdotes about cases in which he had participated. In discussing Congress's exclusive authority to legislate for the District of Columbia, he told the class of an exchange he had with counsel during argument that had surprised him. ${ }^{220}$ In Callan $v$. Wilson, ${ }^{221}$ the government had argued that Congress could suspend the right to a trial by jury in criminal cases, and, according to Justice Harlan, went so far as to say that Congress need not consider the protections of the Bill of Rights when legislating for the District. ${ }^{222}$ Justice Harlan and the Court disagreed: "We held in that case ... that the power given to

215 Robb v. Conolly, 111 U.S. 624 (1884) (Harlan, J.).

216 See Justice Harlan's Lectures, supra note 1, at 173 (Lecture No. 14, Jan. 29, 1898); see also, e.g., id. at 129 (Lecture No. 11, Jan. 8, 1898) (discussing, among other cases, N.Y., New Haven \& Hartford R.R. v. New York, 165 U.S. 628 (1897) (Harlan, J.)).

217 United States v. Ballin, 144 U.S. 1 (1892); see Justice Harlan's Lectures, supra note 1, at 90-91 (Lecture No. 8, Dec. 4, 1897).

218 In re Medley, 134 U.S. 160 (1890); see Justice Harlan's Lectures, supra note 1, at 175 (Lecture No. 15, Feb. 5, 1898) ("When an offense was committed in the state where that particular one was committed, there was no such thing as solitary confinement as a part of the punishment for any length of time, but by the time that man was tried there was a statute of the state which provided for solitary confinement from the time of conviction until the execution, and the question was whether that was ex post facto. Did that add to the man's punishment; did it increase the punishment? A majority of our court held that it did ....").

219 In re Neagle, 135 U.S. 1 (1890) (affirming the circuit court's grant of the writ of habeas corpus by a six to two vote; Justice Harlan being in the majority, and Justice Field taking no part in the case); see Justice Harlan's Lectures, supra note 1, at 232 (Lecture No. 19, March 5, 1898) ("The case is entitled In re Neagle, 135 United States, page 1, opinion by Mr. Justice Miller. I may repeat here what $I$ have stated to you often: that you will derive great profit in understanding the Constitution of the United States in the study of great cases. And if you study that case you will then understand as you have not understood before the full scope of this constitutional requirement that the President of the United States shall take care that the laws be faithfully executed.").

220 See Justice Harlan's Lectures, supra note 1, at 156 (Lecture No. 13, Jan. 22, 1898) ("No doubt the thought will occur to you, what may Congress do in this district? How far may it go? Well, that is an important question. It is easily answered, however, although I have heard arguments made upon that subject that a little surprised me at the time.").

221 Callan v. Wilson, 127 U.S. 540 (1888).

222 Justice Harlan's Lectures, supra note 1, at 156-58 (Lecture No. 13, Jan. 22, 1898); see also Callan, 127 U.S. at 548 ("The contention of the government is, that the Constitution does not require that the right of trial by jury shall be secured to the people of the District of Columbia; . . . that, in adopting the Sixth Amendment, the people of the States were solicitous about trial by jury in the States and nowhere else, leaving it entirely to Congress to declare in what way persons should be tried who might be accused of crime on the high seas, and in the District of Columbia ...."). 
Congress to pass exclusive legislation over this District meant that that legislation must be considered with reference to the fundamental provisions of the Constitution."223 This continues Harlan's theme of extending the protections of the Bill of Rights to the states, and indeed the federal District of Columbia.

\section{E. Harlan's Untimely Departure from Columbian College of Law}

Today, law schools are so desirous of having Supreme Court Justices speak at their campuses-let alone teach-that they fête their guests with every conceivable honor upon their arrival. Justice Harlan did not receive such royal treatment. In fact, he was treated rather crudely by Columbian, and his departure from the law school was abrupt, to say the least.

During the summer of 1910, Ernest G. Lorenzen, Dean of the Department of Law at George Washington University, 224 wrote to Harlan, who at the time was vacationing in Canada, informing him that the faculty decided that the professors would personally contribute funds to pay the salary of the secretary for the law department over the summer, and the amcunt contributed was to be returned in the fall after tuition fees were received. ${ }^{225}$ Harlan replied, noting that he was not consulted about this matter, admittedly because he was out of the country, and agreed to pay his share of $\$ 56.40$, provided that "any further demands upon [him] should be made known in advance." 226 Harlan noted that his salary over the past year at the University was diminished, and his."means are very limited."227

Five days after Dean Lorenzen mailed the letter to Harlan, Walter Clephane, a former student-who went on to participate in seventeen cases before the Supreme Court from 1909 (while Harlan was still on the Court) through $1942^{228}$-wrote to Harlan. ${ }^{229}$ Clephane,

223 Justice Harlan's Lectures, supra note 1, at 157 (Lecture No. 13, Jan. 22, 1898).

224 For an example of Lorenzen's work, see Ernest G. Lorenzen, The Validity of Wills, Deeds and Contracts as Regards Form in the Conflict of Laws, 20 Y ALE L.J. 427 (1911).

225 Letter from Ernest G. Lorenzen to John Marshall Harlan (June 22, 1910) (on file with the Library of Congress, The Harlan Papers, supra note 2, at A2-126), available at http://www. gwlr.org/wp-content/uploads/2013/06/DSC00397.jpg.

226 Letter from John Marshall Harlan to Ernest G. Lorenzen (June 24, 1910) (on file with the Library of Congress, The Harlan Papers, supra note 2, at A2-127), available at http://www. gwlr.org/wp-content/uploads/2013/06/DSC00398.jpg.

227 Id.

228 Penn. Water \& Power Co. v. Fed. Power Comm'n, 315 U.S. 806 (1942); Walker v. Hazen, 302 U.S. 723, 723 (1937); Feiffer v. Mann, 296 U.S. 587 (1935); Allen v. Johnson, 293 U.S. 572 (1934); McGovern v. Hitt, 290 U.S. 637 (1933); Wash. Fidelity Nat'l Ins. Co. v. Burton, 287 U.S. 97, 97 (1932); Reed v. Allen, 286 U.S. 191, 192 (1932); Jewell v. Graham, 277 U.S. 596 (1928); 
who was asked to assist the interim dean, noted the "critical [condition of the University] from a financial standpoint." 230 As it stood, professors would only be paid one-half of their salary during the year, and the balance would be paid at the end of the year, if the tuition fees received "warrant[ed] it."231 Acknowledging the benefit and prestige the Justice brought to the school, Clephane was concerned that Harlan "might not feel that [he] could afford to give the necessary time to the University upon the basis of this reduced compensation." 232 Dean Lorenzen wrote two days later that due to the financial difficulties, the school lowered the requirement for a Bachelor of Laws degree from forty-two hours to thirty-six hours. ${ }^{233}$ As a result, Harlan's constitutional law class was shortened to "two hours for the first semester only," and his salary was reduced by half to $\$ 1500.234$ Lorenzen also notified Harlan, repeating what Clephane wrote, that the faculty would only receive one-half of their salaries each month, with the remainder to be paid at the end of the year. ${ }^{235}$

Harlan replied to Lorenzen on June 25, and sought clarification about the nature of his compensation, asking whether the school would keep the tuition fees separate from the general treasury of the University, because otherwise there was a chance that "nothing [would be] left in the treasury to pay the last half of [his] salary." ${ }^{236}$

Paddon v. Paddon, 268 U.S. 702 (1925); Charles J. Webb \& Co., v. Pingree Cattle Loan Co., 264 U.S. 570, 570 (1924); Lancaster v. Fitch, 262 U.S. 754 (1923); Dahn v. Davis, 258 U.S. 421, 421 (1922); Crutchley v. Nat'l Fireproofing Co., 241 U.S. 664, 664 (1916); Kansas City S. R. Co. v. Guardian Trust Co., 240 U.S. 166, 170 (1916); Taylor v. Columbian Univ., 226 U.S. 126, 130 (1912); Trussed Concrete Steel Co. v. Fidelity Storage Corp., 225 U.S. 716 (1912); Crook v. Int'l Trust Co. of Md., 215 U.S. 613, 613 (1909).

229 Letter from Walter Clephane to John Marshall Harlan (June 25, 1910) (on file with the Library of Congress, The Harlan Papers, supra note 2, at A2-128-130), available at http://www. gwlr.org/wp-content/uploads/2013/06/DSC00399.jpg.

230 Id.

231 Id. at A2-129, available at http://www.gwlr.org/wp-content/uploads/2013/06/DSC00400. jpg.

232 Id.

233 Letter from Ernest G. Lorenzen to John Marshall Harlan (June 27, 1910) (on file with the Library of Congress, The Harlan Papers, supra note 2, at A2-133), available at $\mathrm{http}: / \mathrm{www}$. gwlr.org/wp-content/uploads/2013/06/DSC00404.jpg.

234 Id.; see also Letter from John Marshall Harlan to Walter Clephane (June 28, 1910) (on file with the Library of Congress, The Harlan Papers, supra note 2, at A2-137), available at http:/l www.gwlr.org/wp-content/uploads/2013/06/DSC00408.jpg.

235 Letter from Ernest G. Lorenzen to John Marshall Harlan (June 27, 1910), supra note 233.

236 Letter from John Marshall Harlan to Ernest G. Lorenzen (June 28, 1910) (on file with the Library of Congress, The Harlan Papers, supra note 2, at A2-136), available at http://www. gwlr.org/wp-content/uploads/2013/06/DSC00407.jpg. 
Respectful, though upset, Harlan considered "the whole matter [to be] so serious," that he would write later regarding this matter. ${ }^{237}$ Harlan replied to Clephane, noting that he "must ask time to consider" the reduction in salary and asking Clephane for clarification about the length of his constitutional law class prior to responding to the Dean. ${ }^{238}$

Lorenzen replied to Harlan on June 30, clarified how Harlan would be paid, and assured Harlan that he would ultimately receive his full salary after all tuition fees were received.239 On July 1, Clephane wrote to Harlan, and explained that the L.L.B. degree was shortened from a four-year program to a three-year program, and many courses were shortened, with others eliminated completely. ${ }^{240}$ Harlan then received a check for one-half of his July salary on July 5 , $1910 .{ }^{241}$ Harlan replied to Clephane, and informed him that he would make his decision in about ten days' time. ${ }^{242}$ Harlan's son, James, wrote to him on July 19, 1910, and objected to the university "getting [his] services at [his] time of life for a beggarly compensation." $243 \mathrm{He}$ urged his father not to consent to the reduction in salary, insisting that unpaid back salary should be paid up, and that he set the terms of his employment. ${ }^{244}$ James Harlan refused to allow Snow, the President of the University, and his "termagant wife (who [James thought was] crazy)" to prescribe the terms of the Justice's employment. ${ }^{245}$ James

237 Id.

238 Letter from John Marshall Harlan to Walter Clephane (June 28, 1910) (on file with the Library of Congress, The Harlan Papers, supra note 2, at A2-137), available at http:/www.gwlr. org/wp-content/uploads/2013/06/DSC00408.jpg.

239 Letter from Ernest G. Lorenzen to John Marshall Harlan (June 30, 1910) (on file with the Library of Congress, The Harlan Papers, supra note 2, at A2-139-40), available at http:// www.gwlr.org/wp-content/uploads/2013/06/DSC00411.jpg.

240 Letter from Walter Clephane to John Marshall Harlan (July 1, 1910) (on file with the Library of Congress, The Harlan Papers, supra note 2, at A2-142), available at http:/www.gwlr. org/wp-content/uploads/2013/06/DSC00413.jpg.

241 Letter from Charles F. Holmes, Treasurer, George Washington Univ., to John Marshall Harlan (July 5, 1910) (on file with the Library of Congress, The Harlan Papers, supra note 2, at A2-144), available at http:/www.gwlr.org/wp-content/uploads/2013/06/DSC00415.jpg.

242 Letter from John Marshall Harlan to Walter Clephane (July 8, 1910) (on file with the Library of Congress, The Harlan Papers, supra note 2, at A2-145), available at http://www.gwlr. org/wp-content/uploads/2013/06/DSC00416.jpg.

243 Letter from James Harlan to John Marshall Harlan (July 19, 1910) (on file with the Library of Congress, The Harlan Papers, supra note 2, at A2-146), available at http://www.gwlr. org/wp-content/uploads/2013/06/DSC00417.jpg.

244 Id.

245 Id. at A2-147-148, available at http://www.gwlr.org/wp-content/uploads/2013/06/DSC004 18.jpg. 
Harlan advised his father to insist on his prior salary of $\$ 4,000$, which he had earned several years prior. ${ }^{246}$

Harlan wrote to Dean Lorenzen on July 23, notifying him that he would not resume working at the University in the fall. ${ }^{247}$ In response, A. B. Browne, a trustee of the University, replied, and characterized Harlan's departure as a retirement, noting that "it is both wise and just for you to husband your strength." 248 Such chutzpah to a Justice today would be beyond unimaginable. Harlan took great exception to this misrepresentation, and replied that his resignation was not due to his health, but because his "surroundings had become very disagreeable." 249 Harlan reported that Snow, the President of the University, "had without cause become hostile to every member of [his] family and to [himself]." 250 Harlan claimed that Mrs. Snow was "writing unfriendly letters about [the Harlans] in many directions" and Mr. Snow knew about these actions but "failed to control her."251 Harlan attributed the reduction of his salary, as well as the withholding of his son's salary following his resignation, to Mr. Snow's hostilities. ${ }^{252}$

Harlan replied to Clephane, noting that his health permitted him to continue teaching, though due to "most disagreeable circumstances" he resigned from the University. ${ }^{253}$ In this letter, Harlan shed light on the conflict between the Snows and the Harlans. Mrs. Snow was a cousin of Mrs. Harlan, and imagined that the Harlans desired to "patronize" her and her husband.254 Harlan contended that this was a delusion. ${ }^{255}$ As a result, Mrs. Snow stopped coming to the Harlan

246 Id. at A2-148, available at http://www.gwlr.org/wp-content/uploads/2013/06/DSC00419. jpg.

247 This letter was not in the library's collection, but its content can be derived from the letter sent in response on July 26, 1910. See Letter from A. B. Browne to John Marshall Harlan (July 26, 1910) (on file with the Library of Congress, The Harlan Papers, supra note 2, at A2150), available at $\mathrm{http} / / / \mathrm{www} . g w l r . o r g / w p-c o n t e n t / u p l o a d s / 2013 / 06 / \mathrm{DSC} 00421 . j p g$.

248 Id.

249 Letter from John Marshall Harlan to A. B. Browne (July 29, 1910) (on file with the Library of Congress, The Harlan Papers, supra note 2, at A2-151), available at http://www.gwlr. org/wp-content/uploads/2013/06/DSC00422.jpg.

250 Id.

251 Id.

252 Id. Harlan's son, Richard Davenport Harlan, was the President of Lake Forest College in Illinois from 1901-1905, when he "left for Washington, D.C., to do administrative work at George Washington University." HaRLAN, supra note 117, at insert.

253 John Marshall Harlan to Walter Clephane (July 29, 1910) (on file with the Library of Congress, The Harlan Papers, supra note 2, at A2-151a), available at http://www.gwlr.org/wpcontent/uploads/2013/06/DSC00423.jpg.

254 Id.

255 Id. 
house, and spoke ill of the family "everywhere." 256 Mr. and Mrs. Snow, Harlan contended, "intended to make war upon a Lecturer in the University who had served it for nearly twenty years."257 Harlan's departure was finalized on September 12, 1910, when the Justice mailed his formal resignation to the Board of Trustees of George Washington University. ${ }^{258}$

The chronology of these correspondences coincides with a very significant and unexpected event on the Court. Chief Justice Fuller passed away on July 4, 1910.259 Following the death of Chief Justice Fuller, "John Harlan, as senior associate, acted as chief justice."260 Contemporaneously with his letters to the Dean of the law school and others, he sent several important communiqués to President Taft and Justice Day about the successor to the Chief Justiceship. ${ }^{261}$ There was even some talk about Justice Harlan being promoted to the Chief Justice position. ${ }^{262}$ Perhaps his willingness to resign the job he loved so much was spurred by his desire to be Chief Justice, although this is unlikely, as Harlan himself admitted that he was probably too old for the position. ${ }^{263}$ Further, the conditions at George Washington University had become so uncomfortable, it is fairly clear that this was his true motivation for leaving the University. Remarkably, despite the tumult of the death of the Chief Justice, Harlan was able to communi-

256 Id.

257 Id. at A2-153, available at http://www.gwlr.org/wp-content/uploads/2013/06/DSC00424. jpg.

258 Letter from John Marshall Harlan to Board of Trustees, George Washington Univ. (September 12,1910) (on file with the Library of Congress, The Harlan Papers, supra note 2, at A2-158), available at http:/www.gwlr.org/wp-content/uploads/2013/06/DSC00430.jpg.

259 BETH, supra note 39, at 185.

260 Id. ("During the rest of the summer the work would not have amounted to a great deal, but Harlan undoubtedly had to be in Washington ahead of his colleagues in September in order to make sure the cases were properly scheduled and everything was ready for the coming session.")

261 Read \& Berman, supra note 10, at 61 (citing Letters, John Marshall Harlan to William Howard Taft (July 11, 1910); John Marshall Harlan to William R. Day (July 22, 1910); William R. Day to John Marshall Harlan (July 25, 1910)) ("There is an exchange of letters in 1910 about Harlan's recommendation to President Taft that Justice William R. Day be made Chief Justice following the death of Chief Justice Fuller.").

262 Id. at $61 \mathrm{n} .15$ ("There are letters and clippings indicating a mild campaign on Harlan's behalf for the position."); see also Letter from Henry B. F. MacFarland to John Marshall Harlan (Aug. 2, 1910) (on file with the Library of Congress, The Harlan Papers, supra note 2, at A-2 157), available at http://www.gwlr.org/wp-content/uploads/2013/06/DSC00428.jpg ("As I said to your son some weeks ago, I wish very much that the president would make you Chief Justice of the United States. I believe that appointment would gratify not only your innumerable personal friends but the whole country.").

263 In his letter to Day, Harlan says, "My years forbid [the President's] consideration of my name, even if he had no other objections." Read \& Berman, supra note 10, at $61 \mathrm{n} .15$. 
cate promptly and effectively regarding his position at the school, stressing how significant that job was to him. Only after ten days of deliberation did he officially decide to resign. ${ }^{264}$ This is a testament to his reasonableness and desire for deliberative thought.

\section{F. Origin of the Lecture Notes}

During the 1897-1898 term at the Columbian College of Law, Harlan taught a yearlong constitutional law class. That term, two of Harlan's students decided to practice their shorthand by recording all of his lectures verbatim. ${ }^{265}$ Both students recorded each lecture in shorthand. After comparing their notes, they made a typewritten transcript of each lecture, as well as a letterpress copy on Japanese paper. ${ }^{266}$ At the end of the term, they had transcribed about 500 pages of lectures.

One of the two students was George Johannes, an eighteen-yearold clerk in the Government Printing Office. ${ }^{267}$ Johannes was born in Chicago in 1879, and started working at the Government Printing Office in 1894 , at the age of fifteen. ${ }^{268} \mathrm{He}$ eventually graduated from Columbian College of Law, earning a Master of Laws, and joined the bar of the Supreme Court of the District of Columbia.269 Johannes remained in government service for many years, rising through the ranks of the Department of Commerce and the Labor and the Census Bureau. 270

264 Letter from John Marshall Harlan to Walter Clephane (July 29, 2010), supra note 253.

265 Letter from George Johannes to John Marshall Harlan (Oct. 21, 1955), supra note 2.

266 Id. Japanese paper is a very fine, acid-free, semitransparent mesh paper. About Washi, The Japanese Paper Place, http:/www.japanesepaperplace.com/abt-japanese-paper/aboutwashi.htm (last visited May 30, 2013). A letterpress copy is a mechanical copy of an ink document, made by dampening the document with water, placing it on a piece of thin paper, and pressing the two together with a hand press. Letterpress copies were common from the seventeenth to the early twentieth centuries. James T. Currie, Letter to the Editor, Before Photocopiers, Before Carbons: Letterpress Copies, Chron. Higher Educ. (Oct. 1, 2012), http:// chronicle.com/article/Before-Photocopiers-Before/134756/.

267 Johannes Takes Place of Soleau, WAsh. Herald, Aug. 23, 1911, at 2.

268 Id.

269 Id. Presumably, Johannes also earned a Bachelor of Laws. In 1898, Columbian College of Law offered a Bachelor of Laws, which required two years of study, as well as a Master of Laws, which appears to have required an additional year of study. See Probing the Law School's Past, supra note 77.

270 George Johannes Promoted, Wash. Herald, Oct. 19, 1909, at 5; Items, General and Personal, of Interest to G.P.O. Workers, WAsh. Herald, Oct. 24, 1909, at 8; Johannes Takes Place of Soleau, supra note 267; Geo. Johannes Promoted, WAsH. TimEs, Mar. 28, 1917, at 3. 
Eventually, he went into private practice, joining the Washington, D.C. firm Irelan and Mollohan. ${ }^{271}$ Johannes was counsel of record in several cases before the Court of Appeals for the D.C. Circuit, winning appeals before some legendary circuit judges. In Ramseur $v$. Thompson, ${ }^{272}$ a panel consisting of then-circuit judges Warren E. Burger (future Chief Justice) and David Bazelon affirmed per curiam his favorable ruling before the district court. ${ }^{273}$ Burger would have "dismissed the appeal as frivolous." ${ }^{274}$ In Major $v$. Shaver, 275 a per curiam panel that included Judge E. Barrett Prettyman, ruled in Johannes's favor, and reversed the lower court. ${ }^{276}$ Professor Harlan taught his student well.

On October 28, 1955, Johannes sent his letterpress copy of the lectures to Harlan's grandson at the Supreme Court, the second Justice John Marshall Harlan. ${ }^{277}$ The second Justice Harlan eventually donated Johannes's letterpress copy of the lectures in the Library of Congress.

\section{Harlan's JURISPRUdENCE}

Harlan's lectures provide a unique perspective into his understanding of the Constitution. Unlike his opinions, his lectures are informal, digressive, and personal. As a compendium to this Article, we have also published an annotated transcript of all twenty-seven lectures. $^{278}$ This Section focuses on how Harlan's lectures illuminate his views about the foundation of the United States Constitution, the role history should play in its construction, and how he viewed equal protection, due process, citizenship, and notions of freedom of speech, religious liberty, economic liberty, and gender equality.

271 Letter from George Johannes to John Marshall Harlan (Oct. 21, 1955), supra note 2.

272 Ramseur v. Thompson, 271 F.2d 458 (D.C. Cir. 1959) (per curiam).

273 Id. at 458.

274 Id. (Burger, J., concurring).

275 Major v. Shaver, 187 F.2d 211 (D.C. Cir. 1951) (per curiam).

276 Id. at 213.

277 Letter from George Johannes to John Marshall Harlan (Oct. 21, 1955), supra note 2; Letter from John Marshall Harlan to George Johannes (Oct. 27, 1955) (on file with the Library of Congress, The Harlan Papers, supra note 2, at A2-3), available at http:/www.gwlr.org/wpcontent/uploads/2013/06/DSC00477.jpg; Letter from John Marshall Harlan to George Johannes (Oct. 28, 1955) (on file with the Library of Congress, The Harlan Papers, supra note 2, at A2-4), available at http://www.gwlr.org/wp-content/uploads/2013/06/DSC00478.jpg. Presumably, Johannes kept the letterpress copy and his unidentified friend kept the original.

278 Justice Harlan's Lectures, supra note 1. 


\section{A. Proto-Originalist}

Long before Justices Black or Scalia, Harlan advocated a theory of constitutional interpretation that resembles modern day originalism. As he put it:

Now, it is essential to a clear understanding of our Constitution to know something of the circumstances under which those who framed it were placed. There are words in our Constitution which are susceptible of different constructions, but their meanings are ascertained by knowing the circumstances which then existed and the laws and customs which went before. We ought to know what principles of government existed at the time and before that time, what right of life, liberty, or property existed and which went before the time when the colonies achieved their independence. Every lawyer knows that the meaning of a rule of law is best ascertained by taking the history of the rule, back through the line of legislation and adjudications, up to the time when it was first enacted. ${ }^{279}$

According to Harlan, the meaning of the Constitution is informed by its history, leaving "little or no scope for originality" of interpretation. 280 To Harlan, originalism did not provide for "originality." To understand the scope of Congress's powers under the Commerce Clause, Harlan asked, "When this Constitution was adopted, what did commerce mean?"281 For Harlan, the meaning of "due process" is determined by asking, "[W]hat was due process of law at the time when the Constitution was adopted?"282 Harlan concluded that due process protected every common law right guaranteed at ratification, as specified in the Bill of Rights. ${ }^{283}$ A judgment cannot be rendered against a party not notified of suit. ${ }^{284}$ Government cannot take property for public use without notice or compensation, or for private use in any circumstances. ${ }^{285}$ A prosecution on an information rather than an in-

279 Justice Harlan's Lectures, supra note 1, at 15 (Lecture No. 1, Oct. 14, 1897).

280 Id. at 14.

281 Id. at 118 (Lecture No. 10, Dec. 18, 1897); cf. United States v. Lopez, 514 U.S. 549, 584 (1995) (Thomas, J., concurring) ("Although I join the majority, I write separately to observe that our case law has drifted far from the original understanding of the Commerce Clause. In a future case, we ought to temper our Commerce Clause jurisprudence in a manner that both makes sense of our more recent case law and is more faithful to the original understanding of that Clause.").

282 Justice Harlan's Lectures, supra note 1, at 344 (Lecture No. 27, May 7, 1898).

283 Id.

284 Id.

285 Id. 
dictment is void, as is a prosecution in secret session or without assigned counsel.286 This is the "basis of Anglo-Saxon liberty."287

Harlan placed great importance on understanding the history of English common law, the founding documents, and what the Constitution meant to the Framers. Harlan's first lecture of the term, delivered on October 14, 1897, presents his theory of constitutional jurisprudence in a nutshell. ${ }^{288}$ By comparing the English and American systems of government, Harlan tried to identify the elements of American constitutionalism that make it unique. ${ }^{289} \mathrm{He}$ emphasized that the strength of American government is its stability, created "because in our fundamental law we have placed checks upon ourselves." 290

According to Harlan, the judge represents "the majesty of the law, and that law is above everybody." 291 And for him, that is the key feature of American constitutionalism. ${ }^{292}$ Unlike any other country in the world, in America, any judge, even a justice of the peace, can declare a law unconstitutional and void. ${ }^{293}$ Then Harlan recounts the history of the fundamental rights embodied in the Constitution. They first came into being with the Magna Carta, and were extended by the English Bill of Rights and the Writ of Habeas Corpus. ${ }^{294}$ Harlan lectured to his class about the Magna Carta, and remarked, "in the history of all the Anglo-Saxon race, and many other races, . . . it is the lawyer that has stepped forward and has put himself in the way of arbitrary power to defend the rights of man." 295 These were the fundamental rights at issue in the American Revolution. ${ }^{296}$ In England, Parliament can destroy these fundamental rights by repealing the stat-

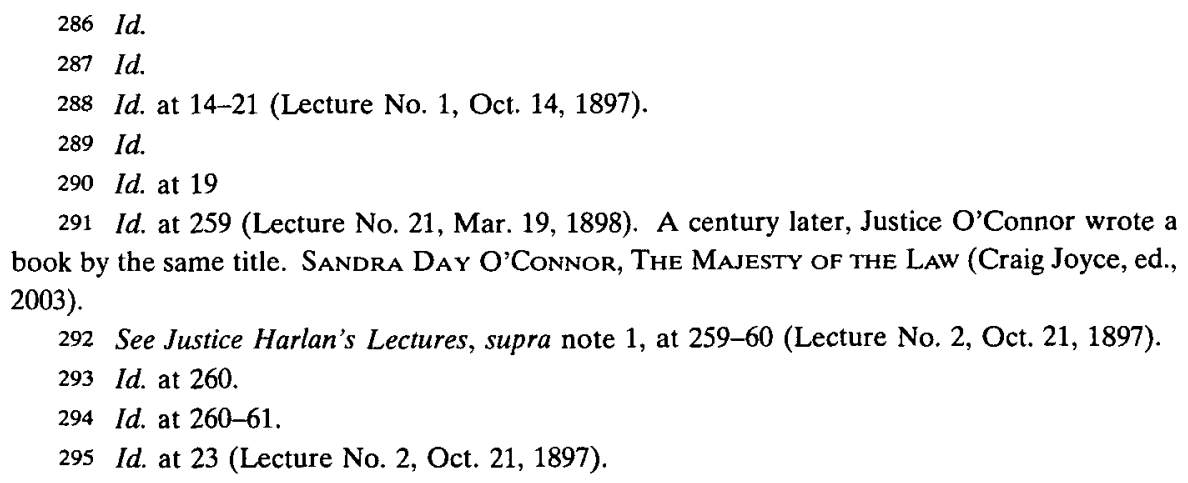

291 Id. at 259 (Lecture No. 21, Mar. 19, 1898). A century later, Justice O'Connor wrote a book by the same title. Sandra Day O'Connor, The Majesty of The Law (Craig Joyce, ed.,

292 See Justice Harlan's Lectures, supra note 1, at 259-60 (Lecture No. 2, Oct. 21, 1897).

293 Id. at 260.

294 Id. at $260-61$.

295 Id. at 23 (Lecture No. 2, Oct. 21, 1897). 2003).

296 Id. at 28-29. 
ute that provides them. ${ }^{297}$ By contrast, the Constitution can only be amended by the people; ${ }^{298}$ Congress cannot alter it on its own. ${ }^{299}$

Harlan was an unabashed admirer of the Federalist Papers. "[I]f you have not got [The Federalist] in your library I advise you to look tomorrow in the secondhand bookstores and see if you cannot buy one for half price, for it is worth its weight in gold."300 Harlan's enthusiasm for The Federalist is matched by modern originalists. For example, Justice Scalia is a great admirer. At a recent seminar, Scalia urged members of Congress to obtain a copy of The Federalist. ${ }^{301}$ One attendee said, "He [Justice Scalia] said we should all get a copy of the Federalist Papers and read it, underline it and dog-ear it."302

Harlan's devotion to the Constitution as he understood it was steadfast. He hoped to convey "safe and sound thoughts about our National Government and the Constitution under which it was organized."303 On the anniversary of Justice Harlan's twenty-fifth year on the court, Justice Brewer said, "Every man has his hobby, and my brother Harlan has as his judicial hobby the Constitution. He has believed that the Constitution and the flag are one now and forever. He has never believed that it was a rope of sand or a cord of rubber." ${ }^{304}$ Harlan's lectures make his passion for the Constitution palpable. On one occasion, after reading the Supremacy Clause, he said, "I love to read these clauses. Let me read one more before we close." 305

Some have referred to Harlan as "the last Whig justice."306 There is some truth to that assessment of his jurisprudence. While Harlan believed that the law should change, he believed that it should change in an orderly fashion, through the legal process, according to tradi-

297 Id. at 260-61 (Lecture No. 21, Mar. 19, 1898). For example, in 2005, Parliament repealed the "double jeopardy" protection for criminal defendants. See Owen Bowcott, Stephen Lawrence Murder Retrial Due to Double Jeopardy Repeal, GuARdian (May 18, 2011, 9:09 AM), http:/www.guardian.co.uk/uk/2011/may/18/double-jeopardy-stephen-lawrence-suspect.

298 Justice Harlan's Lectures, supra note 1, at 296 (Lecture No. 23, Apr. 2, 1898).

299 Id.

300 Id. at 237 (Lecture No. 19, Mar. 5, 1898).

301 Henry C. Jackson, Justice Scalia: Lawmakers Need to Get Familiar with Federalist Papers, Huff Post Politics (Jan. 24, 2011, 10:22 PM), http://www.huffingtonpost.com/2011/01/24/ scalia-tea-party_n_813472.html (quoting Representative Jan Schakowsky).

302 Id.

303 BETH, supra note 39, at 187 (quoting Letter from John Marshall Harlan to Walter Clephane (Aug. 4, 1910) (on file with the Library of Congress, The Harlan Papers, supra note 2)).

304 Justice Harlan at 70, WASH. PosT, June 2, 1903, at 13.

305 Justice Harlan's Lectures, supra note 1, at 297 (Lecture No. 23, Apr. 2, 1898).

306 See BETH, supra note 39. 
tional rules. ${ }^{307}$ However, he did not merely express the nationalist, unionist positions of the only American Whig Party. ${ }^{308}$ When he became a Republican, Harlan adopted some of his new party's latent radicalism. ${ }^{309}$ Yet his version of abolitionism and the Fourteenth Amendment drew on the radical Whig theories of the American Revolution. ${ }^{310}$ His was an ancient, not a modern, Constitution. ${ }^{311}$ As he put it, one should not "accept blindly what the fathers have taught but you ought to be slow in striking down the old landmarks, or ploughing up the old ways." 312

\section{B. American Exceptionalism and Providence}

In his lectures, Justice Harlan expressed a strong belief in American exceptionalism and in the role of providence in America's success. $^{313}$ He saw a tight connection between the rule of law and religion, and considered them both essential to America's prosperity. ${ }^{314}$ For Harlan, constitutional liberty consisted of the common law rights of Englishmen, secured by the Constitution and realized by the Court. ${ }^{315}$ The primary merit of a written Constitution was to render immutable traditional common law rights. ${ }^{316}$ And those common law rights were secured and realized only by special providences, indelibly marked by blood and fire. ${ }^{317}$ Harlan argued that the Fourteenth Amendment incorporated the Bill of Rights against the states. ${ }^{318} \mathrm{He}$ believed that the Constitution expressed the "providential" purpose of the United States. ${ }^{319}$ Discussing the clause that requires that officers must swear to uphold the Constitution, Harlan asks, "Is there any country on the Earth that has in its statutes or laws a provision like that? Not one." 320

307 See id. at 268-69.

308 See id. at 3,86.

309 See id. at 86.

310 See id. at 3.

311 See Justice Harlan's Lectures, supra note 1, at 14-15 (Lecture No. 1, Oct. 14, 1897).

312 BETH, supra note 39, at 150 (quoting Letter from John Marshall Harlan to James S.

Harlan (Sept. 15, 1880) (on file with The John Marshall Harlan Collection, Univ. of Louisville)).

313 See Justice Harlan's Lectures, supra note 1, at 264 (Lecture No. 21, Mar. 19, 1898); id. at 283 (Lecture No. 23, Apr. 2, 1898).

314 PRZYBYSZEWSKI, supra note 3 , at 58.

315 See Justice Harlan's Lectures, supra note 1, at 20-21 (Lecture No. 1, Oct. 14, 1897); id. at 257-60 (Lecture No. 21, Mar. 19, 1898).

316 See id. at 257 (Lecture No. 21, Mar. 19, 1898).

317 PRzybyszewski, supra note 3 , at 48.

318 BETH, supra note 39, at 218.

319 PRZYBYSZEWSKi, supra note 3, at 62.

320 Justice Harlan's Lectures, supra note 1, at 297 (Lecture No. 23, Apr. 2, 1898). 
Praising the values of the separation of powers, Harlan taught:

A government and the only one on the Earth where the heads of it and all the branches of it are governed by a written instrument that says, thus far you may go and no farther, that says to one branch of the government, you may handle this subject, to another, you may handle these subjects, to another branch, you may do this. But it says to all that the law for you and for every human being in this country is this written instrument, which is a power of attorney from the people of the United States to this government. ${ }^{321}$

Harlan even viewed the dreaded Dred Scott decision as:

[A] sort of special providence to this country, in that it laid the foundation of a civil war which, terrible as it was, awful as it was in its consequences in the loss of life and money, was in the end a blessing to this country in that it rid us of the institution of African slavery. That case was the beginning of that struggle..$^{322}$

Harlan revered the founders, especially George Washington, of whom he stated:

We are apt to think, and very rightly, that if it had not been for George Washington, we would not have had the country we now have. We style him "The Father of the Country," and he was. I believe we owe more to him for the adoption of the present form of government than any man of his day. He was not trained in statesmanship, but he had what we may call saving common sense. He was raised up, if there is such a thing as a special providence, to save this country. So far as we now see and can judge, there was no other man of that day that could have led our armies and kept up their courage to the spirit of independence that he did. ${ }^{323}$

Harlan also admired Alexander Hamilton. Marveling at how much Hamilton accomplished at such a young age, he remarked, "[W]henever a great crisis came upon any people, Providence was kind enough to raise up the man to meet the emergency." ${ }^{24}$ Harlan also included Jefferson, Lincoln, and Grant in his list of providential American leaders:

321 Id. at 41 (Lecture No. 3, Oct. 23, 1897) (emphasis added).

322 Id. at 264 (Lecture No. 21, Mar. 19, 1898) (emphasis added).

323 Id. at 111-12 (Lecture No. 9, Dec. 11, 1897) (emphasis added).

324 Id. at 239 (Lecture No. 19, Mar. 5, 1898) (emphasis added). 
We sometimes are in the habit in our ordinary conversation of speaking of particular things which have occurred as providences: "That was a special providence." We say that George Washington was a special providence, that he was raised up for the work he did, and that no other man could have done the work-so far as we can tell-that he did. We say that Jefferson was a special providence, and that no other man could have performed the work that he did. We talk in the same way about Abraham Lincoln, and about Ulysses S. Grant in the same sense. ${ }^{325}$

At the conclusion of the last lecture, on May 7, 1898, three weeks after Congress declared war on Spain, Justice Harlan stressed the power of American exceptionalism:

If the world never knew so before [of America's prowess], they have been convinced within the last fortnight that this great republic of ours, in all the future destinies of the world, is to be reckoned with in the government of European affairs. And that the power on this Earth today that is likely to shape the destinies of Europe and the Far Eastern countries, and of the whole human race in the next century, are the United States of America. ${ }^{326}$

Like many Americans of his day, Harlan deeply believed that America represented the world's best hope for liberty and justice.

Harlan's republicanism committed him to popular sovereignty, civic virtue, and self-governance. Other Justices saw the rights guaranteed by the Constitution as abstract, derived from reason and practicality. For some, like Holmes and Brandeis, it meant legal realism. ${ }^{327}$ By contrast, Harlan saw constitutional rights as elements of a shared culture, and the extension of them to the states through the Constitution as a means of promoting and preserving national unity. By affirming a common American heritage, rooted in "Anglo-Saxon" liberties, the Court, through the Bill of Rights and the constitutional privileges and immunities it protected, could help create a unified nation, one with the ideological strength to overcome sectional and racial differences. ${ }^{328}$ Harlan's lectures were one tool for accomplishing this goal.

325 Id. at 264 (Lecture No. 21, Mar. 19, 1898) (emphasis added).

326 Id. at 347 (Lecture No. 27, May 7, 1898) (emphasis added).

327 See generally Oliver Wendell Holmes, The Common Law (Boston, Little, Brown \& Co. 1881); see also Olmstead v. United States, 277 U.S. 438, 471 (1928) (Brandeis, J., dissenting). 328 See Justice Harlan's Lectures, supra note 1, at 15 (Lecture No. 1, Oct. 14, 1897). 


\section{American Citizenship and Equal Protection}

One of Harlan's most passionate lectures was his discussion of United States $v$. Wong Kim Ark ${ }^{329}$ on March 19, 1898. ${ }^{330}$ In Wong Kim Ark, the Supreme Court considered whether birth in the United States was sufficient to grant United States citizenship to a person of Chinese descent. ${ }^{331}$ The Court, in a 6-2 decision by Justice Gray, held that Wong Kim Ark, who was born in the United States to Chinese citizens, acquired American citizenship at birth by the principle of jus soli. ${ }^{332}$ Chief Justice Fuller, joined by Justice Harlan, dissented, arguing for the principle of $j u s$ sanguinis, under which a child inherits citizenship from his or her father, regardless of birthplace. ${ }^{333}$

Wong Kim Ark was argued on March 5 and 8, 1897.334 When Harlan discussed it in class on March 19, 1898, he expressed views closely reflecting the dissent he eventually joined. ${ }^{335}$ Harlan argued that Chinese-Americans could not be assimilated into the American populace, and thus were not entitled to birthright citizenship under the Fourteenth Amendment. ${ }^{336}$ The case would be decided nine days later on March 28, 1898, after which Harlan explained how he reconciled his views with those of the majority. ${ }^{337}$ This discussion illuminates Harlan's chimerical views on race, and juxtaposes his enlightened dissents in Plessy v. Ferguson ${ }^{338}$ and the Civil Rights Cases $^{339}$ with his xenophobic views in Wong Kim Ark.

\section{A Preview of Wong Kim Ark in Class}

Harlan was quite passionate, and certain, about his views on birthright citizenship. During his lecture on March 19, 1898, Justice Harlan had just finished discussing the importance of Dred Scott in bringing about the end of slavery when he considered birthright citizenship for three classes of people-the son of a freedman, an Indian, and a "Chinaman." ${ }^{340}$ Justice Harlan used this pending case as a vehi-

\footnotetext{
329 United States v. Wong Kim Ark, 169 U.S. 649 (1898).

330 Justice Harlan's Lectures, supra note 1, at 266 (Lecture No. 21, Mar. 19, 1898).

331 Wong Kim Ark, 169 U.S. at 653.

$332 I d$. at $652,667,705$.

333 Id. at 732 (Fuller, C.J., dissenting).

334 Id. at 649.

335 Justice Harlan's Lectures, supra note 1, at 266-68 (Lecture No. 21, Mar. 19, 1898).

336 Id.

337 Id. at 342-43 (Lecture No. 27, May 7, 1898).

338 Plessy v. Ferguson, 163 U.S. 537, 552 (1896) (Harlan, J., dissenting).

339 The Civil Rights Cases, 109 U.S. 3, 26 (1883) (Harlan, J., dissenting).

340 See Justice Harlan's Lectures, supra note 1, at 266-68 (Lecture No. 21, Mar. 19, 1898).
} 
cle to discuss Congress's Article I power to establish a uniform rule of naturalization and whether the Fourteenth Amendment curtailed "Congress['s] [power] to establish a uniform rule of naturalization." 341

A child of "African descent" is born in Tennessee, Harlan hypothesized, and his "father was before him, freed by the Thirteenth Amendment, [and] made a freeman." ${ }^{342}$ Would the child be a citizen?

Now, that man, whatever Tennessee may think about him, however much she may grumble about it-if she does ...-that man is not only a citizen of the United States, but he is a citizen of the state of Tennessee, because he was born in the United States, and born subject to the jurisdiction of the United States. ${ }^{343}$

But "Judge," a student interjects, "does that include Indians?" ${ }^{444}$ The answer: "No." 345 Harlan cited the "very learned opinion . . . by the majority of the Court" ${ }^{346}$ in Elk v. Wilkins, ${ }^{347}$ in which an Indian, born on a reservation, "left his tribe and came into the state of $\mathrm{Ne}$ braska, intending to become a part of that people." ${ }_{348}$ The Court "thought that he could not become a citizen of the United States." ${ }^{349}$ Harlan, who did not join that "learned opinion," "had the misfortune to differ from the Court upon that question, and of course [he] was wrong." ${ }_{350}$ Harlan would have found someone born on an Indian reservation to be a citizen of the United States. ${ }^{351}$

Would a Chinaman born in this country be a citizen?

We have now before us under consideration this case, and when I tell you the case you will probably understand why I cannot answer your question, as it has not been decided. It will be decided some of these days. ${ }^{352}$

Nonetheless, Harlan proceeded to give his views on the topic. Harlan described the facts of the case, wherein "a subject of the Emperor of China ... [gave birth to] a male child." 353 Wong Kim Ark,

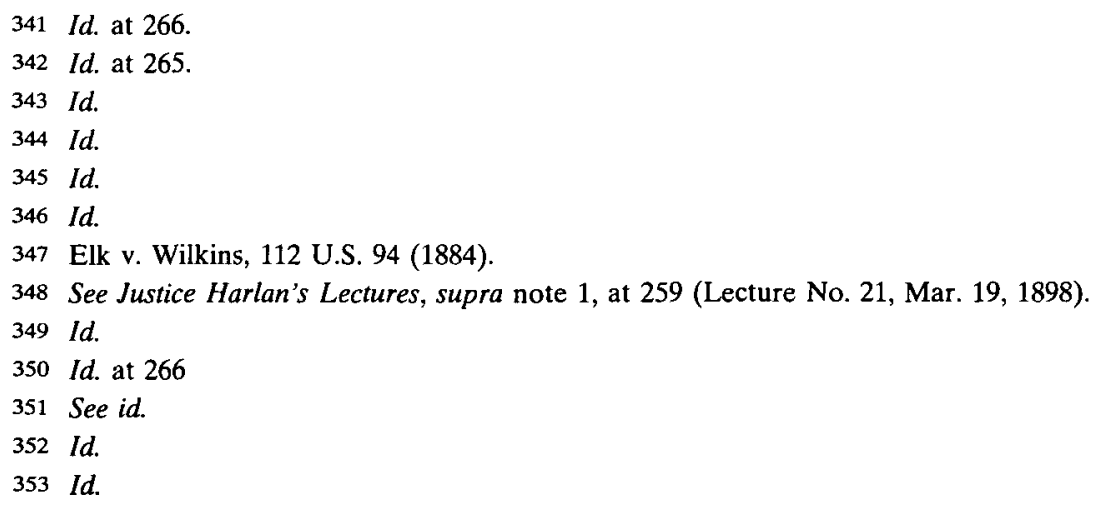


the son, now claims citizenship of the United States, "although his parents when he was born and still are today the subjects of the Emperor of China." $354 \mathrm{He}$ begins, "[w]e have for many years had the policy," and catches himself in midsentence, interjecting, "I am now giving you the argument on one side." He continues noting the longstanding policy to exclude the Chinese from America, because:

[T] his is a race utterly foreign to us, and never will assimilate with us. They are pagans in religion, so different from us that they do not intermarry with us, and we don't want to intermarry with them .... [N]o matter how long they have been here, they make arrangements to be sent back to their fatherland. [Thus] there is a wide gulf between our civilization and their civilization, and we don't want to mix..$^{355}$

This belief mirrors one of the lesser known aspects of his legendary Plessy v. Ferguson dissent: "There is a race so different from our own that we do not permit those belonging to it to become citizens of the United States. Persons belonging to it are, with few exceptions, absolutely excluded from our country. I allude to the Chinese race." 356

Harlan poses a series of hypotheticals of what "would have been the condition today of the states of California, Oregon, Washington, Nevada, and Utah . . . if we had no restriction whatever against the admission of Chinese in this country." 357 Fearing that if "fifty million" of the "two or three hundred million" in China immigrated to the "Pacific slope" with no restrictions, these states "would have been dominated by that race. They would have rooted out the American population that is there, would have compelled all of the laboring part of that country to have left and come to other parts of the country to seek subsistence." 358

Harlan queries:

Can it be possible that the Fourteenth Amendment had the effect of tying the hands of the Congress of the United States in the matter of naturalization, so that children born in this country of people who are Chinese subjects, and who always remain such, should become citizens of the United States?359

356 Plessy v. Ferguson, 163 U.S. 537, 561 (1896) (Harlan, J., dissenting).

357 Justice Harlan's Lectures, supra note 1, at 267 (Lecture No. 21, Mar. 19, 1898).

358 Id.

359 Id. 
Harlan feared a scenario wherein a "father and mother [of a] race [that was] excluded from this country ... [had a] son by the accident of his birth in this country" who would be "eligible to the Presidency of the United States." 360

[By] the same principle ... if some of our own people, American-born and their ancestors American-born ... . [should give birth to a child] while . . . traveling in foreign lands . . . that son would not be a citizen of the United States [because he was neither born in the United States nor naturalized in the United States]. ${ }^{361}$

Harlan asks if the Fourteenth Amendment should have "the effect of tying the hands of the Congress" so that children of Chinese subjects should become citizens of the United States. ${ }^{362}$ Harlan dedicates but a single sentence to presenting the "argument on the other side," which focuses on the words of the Fourteenth Amendment, which "embrace just such a cause." 363 Notwithstanding his excessive commentary on the issue, Harlan notes that he "do[es] not think [he] can answer [the questions] yet." ${ }^{364} \mathrm{He}$ concludes by noting, "When the case is decided I will try and bring it to the attention of the class. How it may be decided, I do not know. If I did, I would not say."365 But, he most certainly did know how the case would be resolvedeven if he did not say.

\section{A Recap of Wong Kim Ark in Class}

Justice Harlan more than showed his cards as to how he thought the case should be decided. United States v. Wong Kim Ark was decided nine days later on March 28, 1898. ${ }^{366}$ In that case, Justice Harlan joined Chief Justice Fuller's dissent, arguing that a "Chinaman" born in the United States to parents who were still subjects of China could not become a citizen. ${ }^{367}$ Many of Chief Justice Fuller's arguments tracked closely with the argument Harlan presented in his lectures.

Both Harlan's lectures and Fuller's opinion note the unwillingness of Chinese immigrants to assimilate and their continued loyalty

360 Id. For further discussions on the meaning of "Natural Born Citizen," see generally Josh Blackman, Original Citizenship, 159 U. PA. L. Rev. PENNumbra 95 (2010).

361 Justice Harlan's Lectures, supra note 1, at 268 (Lecture No. 21, Mar. 19, 1898).

362 Id.

363 Id.

364 Id.

365 Id.

366 United States v. Wong Kim Ark, 169 U.S. 649, 649 (1898).

367 See id. at 715 (Fuller, C.J., dissenting). 
to the Emperor of China. ${ }^{368}$ Both also make the exact same comment that the Framers could not have interded a foreigner born by accident in the United States to be eligible to run for President, while children of American citizens born abroad were not:

Considering the circumstances surrounding the framing of the Constitution, I submit that it is unreasonable to conclude that "natural-born citizen" applied to everybody born within the geographical tract known as the United States, irrespective of circumstances; and that the children of foreigners, happening to be born to them while passing through the country, whether of royal parentage or not, or whether of the Mongolian, Malay or other race, were eligible to the Presidency, while children of our citizens, born abroad, were not. ${ }^{369}$

Harlan held deeply the beliefs he lectured about in class, as he vigorously argued in favor of his position, but only casually mentioned the other side's argument in a single sentence. ${ }^{370}$ One could wonder how much influence Harlan had in the authorship of Fuller's dissent, or if Harlan himself had authored parts of it but chose not to claim ownership.

After the Court decided Wong Kim Ark, Justice Harlan revisited his previous position on May 7, 1898 when discussing the Citizenship Clause of the Fourteenth Amendment. ${ }^{371}$ He remarked, "[w]e had an illustration of the application of [the Fourteenth Amendment] in the present term of our Court." 372 The "question turns upon two or three words of this amendment"-actually five words-"subject to the jurisdiction thereof." 373 If Wong Kim Ark "was within the meaning of that clause, 'subject to the jurisdiction' of the United States, then he became a citizen of the United States, and of the state wherein he resided. The majority of the Court held that he was." 374 "The

368 Id. at 725 ("Generally speaking, I understand the subjects of the Emperor of Chinathat ancient Empire, with its history of thousands of years and its unbroken continuity in belief, traditions and government, in spite of revolutions and changes of dynasty-to be bound to him by every conception of duty and by every principle of their religion, of which filial piety is the first and greatest commandment . . . "); see also Justice Harlan's Lectures, supra note 1, at 266 (Lecture No. 21, Mar. 19, 1898).

369 Wong Kim Ark, 169 U.S. at 715 (Fuller, C.J., dissenting).

370 Justice Harlan's Lectures, supra note 1, at 266 (Lecture No. 21, Mar. 19, 1898).

371 Id. at 342 (Lecture No. 27, May. 7, 1898).

372 Id.

$373 I d$.

$374 I d$. 
minority," which Harlan joined, "held that he was not born [subject] to the jurisdiction of the United States." 375

Harlan explained his reasoning, observing that "[h]e was not born subject to the political jurisdiction of the United States. Of course, he owed allegiance to our laws, as every man who comes here, but he was not born under the jurisdiction of the United States, within the meaning of this article of the Constitution." ${ }^{376}$ This mirrors the statement Senator Lyman Trumbull of Illinois made during the ratification debates of the Fourteenth Amendment, cited in the Wong Kim Ark dissent: "What do we mean by 'subject to the jurisdiction of the United States'? Not owing allegiance to anybody else; that is what it means." 377

Harlan revisits the example he posed in his earlier class, that was discussed in Wong Kim Ark, wherein an "English father and mother went down to Hot Springs [in Arkansas] to get rid of the gout ... and while [they were] there, there is a child born." 378 The boy goes back to England. "Is this child a citizen of the United States, born to the jurisdiction thereof, by the mere accident of his birth?"379 Harlan answers no. ${ }^{380}$ His reasoning is more expansive, no longer focusing on his xenophobic views of the Chinese, but more broadly denying birthright citizenship to anyone subject to the loyalty of any foreign power. "My belief [was that the Fourteenth Amendment] was never intended to embrace everybody in our citizenship if he was the child of parents who cannot under the law become naturalized in the United States." 381 While Congress can grant citizenship to the parents of natural born citizens, Harlan was unable to believe that "when the boy's parents could not become citizens of the United States [through the Constitution, or laws of Congress at that time], that it was possible for [the boy] to become a citizen of the United States."382 Closing with charm, Harlan conceded, "[o]f course, I am wrong, because only the Chief Justice and myself held these views, and as the majority decided the other way, we must believe that we were wrong." ${ }^{83}$

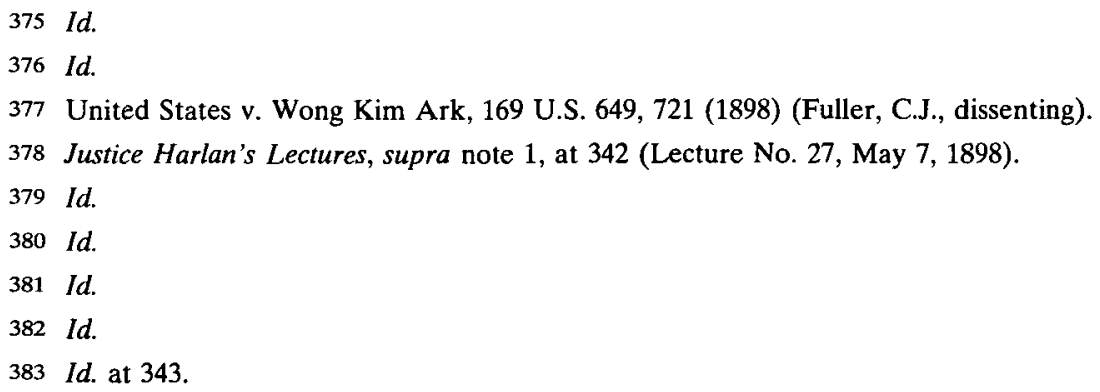


With his trademark wit, Harlan conceded, "I was one of the minority, and of course I was wrong." 384

\section{Harlan's Enigmatic Approach to Equality}

It is perplexing how Justice Harlan could have such a narrow conception of citizenship for Chinese immigrants, given his broad view of the rights of freed slaves. He alone on the court took the progressive position that the Thirteenth and Fourteenth Amendments authorized Congress to prohibit racial discrimination by private parties. ${ }^{385}$ Harlan stated that the Equal Protection Clause "says to the states, take care that you do not apply class legislation," especially laws discriminating on the basis of race or color. ${ }^{386}$ And most remarkably, in Plessy v. Ferguson, Harlan alone argued that the Fourteenth Amendment prohibits "separate but equal" accommodations. ${ }^{387}$ These egalitarian principles are reflected in his lectures. When discussing the Fourteenth Amendment, Harlan boldly proclaimed, "Therefore, it follows that every negro in the United States, if he had been born there or has been naturalized in the United States, when [the Fourteenth Amendment] was adopted became a citizen of the United States and of the state wherein he resided." 388

Harlan also grounded the Constitution's protections for the freedmen in the Privileges and Immunities Clause of Article IV and its expansion by the Fourteenth Amendment. ${ }^{389}$ The Constitution originally spoke only of citizens of the states. The Fourteenth Amendment makes all persons born in the United States and subject to its jurisdiction citizens of both the state in which they live and the United States. Harlan characterizes this as a repudiation of Dred Scott, which held that blacks could not claim privileges and immunities, because they could not be a citizen of a state without its consent. ${ }^{390}$

He criticized those who lament the demise of slavery as of a "past generation" and as parasites on society. ${ }^{391}$ Harlan, the former slave owner who fought on behalf of the Union, considered slavery a great evil, which created a division among the American people. ${ }^{392}$ For

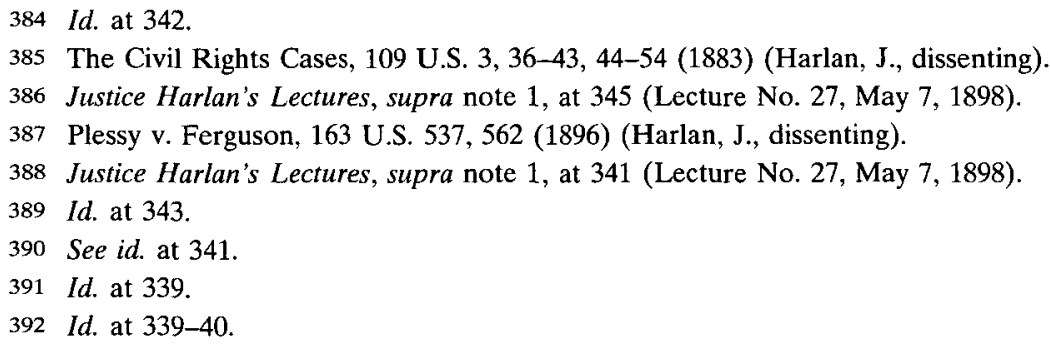


Harlan, an important aspect of the evil of slavery was this division. Southerners were expected to view slavery as of "divine origin" and Northerners could not "treat with Christian moderation" Southerners who supported it. ${ }^{393}$ Harlan's views on race-contrary to the colorblindness ascribed to him by the Supreme Court a century later ${ }^{394}$ can even be seen to support race-based preferences:

[I]f there is a black man who can get ahead of me, I will help him along, and rejoice. And his progress in life does not excite my envy. And I am glad to feel and know that it is the desire of the white people in this country that that race shall push themselves forward in the race of this life. ${ }^{395}$

Harlan, however, viewed the Civil Rights Amendments to solely benefit freed slaves, and not Chinese aliens, who were inherently unAmerican, ${ }^{396}$ and did not assimilate into American culture. His views on equal protection cannot be fully understood unless one considers how he viewed Chinese-Americans, and their inability to obtain birthright citizenship. ${ }^{397}$

Harlan's lone dissent in Plessy has come to exemplify his prescience and his greatness. According to Loren P. Beth, it is "an appeal to the conscience of the future: it is thus to be judged on whether it correctly divined that conscience," and "the box score on Harlan is perhaps higher than that of any man who has ever occupied the bench." 398

And yet, one recent biographer, confounded by the impossibility of reconciling Harlan's constitutional thought with contemporary constitutional jurisprudence, concluded that he was a "judicial enigma." 399 As another recognized, "so great is the chasm between Harlan and us that some of his words in Plessy seem to make no sense at all." ${ }^{400}$ And

393 Id. at 340.

394 Parents Involved in Cmty. Sch. v. Seattle Sch. Dist. No. 1, 551 U.S. 701, 788 (2007) (Kennedy, J., concurring) ("And, as an aspiration, Justice Harlan's axiom must command our assent. In the real world, it is regrettable to say, it cannot be a universal constitutional principle.").

395 Justice Harlan's Lectures, supra note 1, at 341 (Lecture No. 27, May 7, 1898) (emphasis added).

396 See United States v. Wong Kim Ark, 169 U.S. 649, 724 (1898) (Fuller, C.J., dissenting) (asserting that the Fourteenth Amendment is for the benefit of freed slaves, and not aliens).

397 For more on Justice Harlan's views on Chinese-Americans, see generally Gabriel J. Chin, The Plessy Myth: Justice Harlan and the Chinese Cases, 82 lowA L. REv. 151 (1996).

398 Loren P. Beth, Justice Harlan and the Uses of Dissent, 49 AM. PoL. Scr. Rev. 1085, 1086 (1955)

399 See YARBRoUgh, supra note 3.

400 PrZybyszewski, supra note 3, at 204. 
that is true, as far as it goes. But Harlan's Plessy dissent is not "strange" merely because it assumes a social reality in which free blacks still serve whites, making segregation an absurd burden on both. ${ }^{401}$ Rather, it and Harlan's other myriad dissents, concurrences, and opinions are also "strange" because they assume an understanding of the nature of the Constitution very different from our own. Harlan was indeed an enigma, and his lecture notes only begin to shed light on this complicated judicial giant.

\section{Individual Liberty}

Harlan's conception of individual liberty was closely tied to his view of exceptionalist American liberty. He viewed freedom of speech and freedom of the press as distinctly American treasures, standing in stark contrast to European censorship. ${ }^{402}$ Harlan viewed religion as an important component of any virtuous state; thus, he construed the Establishment Clause quite narrowly, agreeing that a state, as opposed to the federal government, could establish a religion. ${ }^{403}$ Harlan's lectures presage his ultimate dissent in Lochner $v$. New York, where he recognized the importance of the state to protect health and safety, and he declined to second-guess the wisdom of legislators in that case. ${ }^{404}$ Finally, Harlan took a textually provincial view of gender equality, noting that women could not vote under the Fifteenth Amendment-though a woman could be elected President, as the qualifications in Article II are gender neutral. ${ }^{405}$

\section{Freedom of Speech}

After reading from the First Amendment, "Nor shall Congress 'abridge the freedom of speech, or of the press," Harlan asked, "What is freedom of speech?" ${ }^{406}$ Taking it almost for granted that Americans understood what freedom of speech meant-and taunting us a century later-he answered, "Well, I need not say what that is in America. We certainly have a great deal of free speech here, and we know what freedom of the press is." 407 Like Justice Potter Stewart,

401 Id.

402 Justice Harlan's Lectures, supra note 1, at 303-05 (Lecture No. 24, Apr. 16, 1898).

403 Id. at 312-13 (Lecture No. 25, Apr. 23, 1898).

404 Lochner v. New York, 198 U.S. 45, 65, 69 (1905) (Harlan, J., dissenting).

405 Justice Harlan's Lectures, supra note 1, at 346 (Lecture No. 27, May 7, 1898).

406 Id. at 303 (Lecture No. 24, Apr. 16, 1898).

407 Id 
Harlan knew it when he saw it. ${ }^{408}$ Harlan noted that the press has wide latitude to publish what it sees fit, whether true or false:

We have not only got freedom of the press, but you might call it the "licentiousness of the press." If there is anything that a newspaper wants to say, it says it. And it says a great many things that are not so, but it says them, and you cannot suppress it. You can hold the manager of that paper responsible for any libel, but that is practically all. ${ }^{409}$

When he refers to a libel suit against the manager of a newspaper, Harlan was likely alluding to the famous trial of John Peter Zenger in 1735 , in which a jury acquitted Zenger, a newspaper publisher, of a charge of seditious libel, finding truth was a defense to libel. ${ }^{410}$ In 1897 , such a manager would not yet be protected by the "actual malice" standard of New York Times Co. v. Sullivan. ${ }^{411}$

Harlan, in fact, would rather have a press that peers into public, as well as private, matters instead of countenancing censorship of the press, as seen in Europe:

The newspapers of this country are great searchlights that are looking into everything, not only that which concerns the public, but that which does not concern the public. And the privilege is abused. But we had better stand it abused than to have the press subjected-as it is on the continent of Europe-to a sort of censorship, under which somebody sitting near a telegraph office in a room adjoining, says by the authority of government that no telegrams shall go from this office to a foreign country unless submitted to this censor. And he strikes this out and that out and the other out, so that if in such a government they do not want the truth known, it keeps it back.

Well, we have no trouble of that sort in this country. We have not only got the truth, but we have got more than the

408 See Jacobellis v. Ohio, 378 U.S. 184, 197 (1964) (Stewart, J., concurring) ("I shall not today attempt further to define the kinds of material I understand to be embraced within that shorthand description [of obscene pornography]; and perhaps I could never succeed in intelligibly doing so. But $I$ know it when I see it, and the motion picture involved in this case is not that." (emphasis added)).

409 Justice Harlan's Lectures, supra note 1, at 303-04 (Lecture No. 24, Apr. 16, 1898) (emphasis added).

410 Doug Linder, The Trial of John Peter Zenger: An Account, U. Mo.-KAN. CiTY SCH. L. (2001), http://law2.umkc.edu/faculty/projects/ftrials/zenger/zengeraccount.html.

411 See New York Times Co. v. Sullivan, 376 U.S. 254, 280 (1964) (noting that a statement about a public official must have been made with " actual malice' - that is, with knowledge that it was false or with reckless disregard of whether it was false or not" for that official to recover damages for defamation relating to official conduct). 
truth constantly traveling in the telegrams and newspapers. I say better that-a thousand times better-than any condition of things that would subject the press or speech of this country to a governmental censorship. ${ }^{412}$

Harlan's view on permitting the press to cover that which is public, and private, stands somewhat in contrast with those of his contemporary legal scholar (and future Supreme Court Justice) Louis Brandeis, who, along with Samuel D. Warren, had written The Right to Privacy in the Harvard Law Review seven years earlier in 1890.413 As Warren and Justice Brandeis lamented, newly invented portable cameras "rendered it possible to take photographs surreptitiously," 414 greatly weakening the right of people to live private lives. In response to this new phenomena, with the goal to prevent the "evil of the invasion of privacy by the newspapers" and to "afford some remedy for the unauthorized circulation of portraits of private persons," Warren and Justice Brandeis set out to build from the blocks of existing common law a right to privacy that would protect the "privacy of the individual." 415 Analyzing other doctrines of law, including slander, libel, trade secret, and intellectual property, the scholars formed "the right 'to be let alone." "416 This right was-and remains to this day-in some tension with the First Amendment. ${ }^{417}$ Harlan, however, would give the presumption to the side of liberty. ${ }^{418}$

\section{Religious Liberty}

Harlan was a devout Presbyterian, and remained deeply religious throughout his life. ${ }^{419}$ His opinions often reflect religious beliefs. ${ }^{420}$ After teaching a Saturday night class at the law school, he would teach

412 Justice Harlan's Lectures, supra note 1, at 304 (Lecture No. 24, Apr. 16, 1898).

413 Samuel D. Warren \& Louis D. Brandeis, The Right to Privacy, 4 Harv. L. Rev. 193 (1890).

414 Id. at 211.

415 Id. at $195,197$.

416 Id. at 194-95 (quoting Thomas M. Cooley, A Treatise on the Law of Torts 29 (Chicago, Callaghan \& Co. 1888)).

417 See Josh Blackman, Omniveillance, Google, Privacy in Public, and the Right to Your Digital Identity: A Tort for Recording and Disseminating an Individual's Image Over the Internet, 49 Santa Clara L. Rev. 313, 327 (2009).

418 Justice Harlan's Lectures, supra note 1, at 304 (Lecture No. 24, Apr. 16, 1898). See also generally Randy Barnett, Restoring the Lost Constitution: The Presumption of LibERTY (2004); Josh Blackman, The Constitutionality of Social Cost, 34 HaRv. J.L. \& PuB. Pol'y 951 (2011).

419 James W. Gordon, Religion and the First Justice Harlan: A Case Study in Late Nineteenth Century Presbyterian Constitutionalism, 85 MARQ. L. REV. 317, 317 (2001).

$420 I d$. at 380 . 
a men's Bible class Sunday morning at the Presbyterian Church in Washington. ${ }^{421}$ Harlan often weaved the scripture into his lectures. When discussing the uniqueness of the United States Supreme Court, Harlan noted, "[w]here the thought originated of one Supreme Court, I do not know. They certainly did not borrow it from any country on the Earth . ... It seems to have come providentially into this instrument . . ." 422 Harlan also wove humor and scripture together, remarking "The scriptures, I believe, say-these young gentlemen here that read their Bible every morning will correct me if I am wrongthat the poor ye have always with you. And so you have the Supreme Court of the United States always with you." ${ }^{423}$ Broadly speaking, Congress cannot eliminate the Supreme Court's original jurisdiction. With a finer point, Harlan conveyed that no one can get rid of the Supreme Court.

Harlan also recognized that religion played an important role in the providence of American success, through its grand Constitution. In a speech given at the Columbian Law School banquet in 1897, Harlan remarked that he placed the law "next to the church, because out of the legal profession there came the spirit of order and the sense of right." 424 Harlan also viewed religion as a key element in any virtuous society: "[I]f in the experience of the last two or three hundred years you point me to any people anywhere on the earth which have no Sabbath, I will point you to a people that have the seeds of destruction in their social organization." "425

Harlan's reading of the Establishment Clause ${ }^{426}$ might very well seem unthinkable to most Americans today, save for Justice Clarence Thomas. ${ }^{427} \mathrm{He}$ asserted unequivocally that there is nothing in the Constitution that would stop a state, as opposed to the federal government, from establishing an official religion for itself: "[T]his First Amendment of the Constitution relates only to the powers of the United States, and there is nothing in that clause of the Constitution

421 Read \& Berman, supra note 10, at 66 ("He also taught a men's Bible class at the New York Avenue Presbyterian Church in Washington for many years and was active in Presbyterian affairs.").

422 Justice Harlan's Lectures, supra note 1, at 239 (Lecture No. 19, Mar. 5, 1898) (emphasis added).

423 Id. at 234.

424 Columbian Law School Banquet, supra note 128.

425 Justice Harlan's Lectures, supra note 1, at 26 (Lecture No. 2, Oct. 21, 1897).

426 U.S. CONST. amend. I ("Congress shall make no law respecting an establishment of religion .....").

427 See infra notes $434-35$ and accompanying text. 
which would prevent a state from establishing a religion." 428 Harlan notes that Virginia had an established religion at the time of the adoption of the Constitution, but that upon its ratification, James Madison-backed by Thomas Jefferson and others-led the fight in Virginia to amend the Commonwealth's Constitution to abolish the established religion. ${ }^{429}$ Their efforts were successful. ${ }^{430}$

However, Harlan asserts:

[T]here is another clause of the Constitution of the United States that would have more direct bearing on that, and that is the clause in the original Constitution to the effect that the United States shall guarantee to every state in the [U]nion a republican form of government.

It may very well be doubted whether a state which had an established religion would have a republican form of government. ${ }^{431}$

This reference to the Guarantee Clause ${ }^{432}$ is notable for its seeming inconsistency with some of Harlan's other lectures where he mentions that this particular clause has never been found to present a justiciable question-that is, there are no judicially cognizable standards by which such a question could be resolved. ${ }^{433}$ Though Harlan's view of the Establishment Clause has largely been repudiated by the Supreme Court, ${ }^{434}$ Justice Thomas has adopted a similar position. ${ }^{435}$

428 Justice Harlan's Lectures, supra note 1, at 312 (Lecture No. 25, Apr. 23, 1898).

429 See id. at 313.

430 Id.

431 Id. at 312 (referring to U.S. Const. art. IV, § 4).

432 U.S. Const. art. IV, $\S 4$.

433 See, e.g., id. at 312 (Lecture No. 23, Apr. 2, 1898); id. at 225 (Lecture No. 18, Feb. 26, 1898); see also Luther v. Borden, 48 U.S. (7 How.) 1, 42 (1849) (holding that the Guarantee Clause is not justiciable).

434 See, e.g., Lee v. Weisman, 505 U.S. 577, 590 (1992) ("The suggestion that government may establish an official or civic religion as a means of avoiding the establishment of a religion with more specific creeds strikes us as a contradiction that cannot be accepted."); Cnty. of Allegheny v. ACLU, 492 U.S. 573, 600-02 (1989) (summarizing the Court's refinement of the Establishment Clause and finding the crèche in the county courthouse violated the establishment clause); Lemon v. Kurtzman, 403 U.S. 602, 603, 612-13 (1971) (using three-part test to find two states' laws granting financial support to church-related, private education violated the Establishment Clause). For a summary of pre-Lemon Establishment Clause jurisprudence, see Josh Blackman, This Lemon Comes as a Lemon: The Lemon Test and the Pursuit of a Statute's Secular Purpose, 20 Geo. Mason U. C.R. L.J. 351, 353-55 (2010).

435 See Elk Grove Unified Sch. Dist. v. Newdow, 542 U.S. 1, 50 (2004) (Thomas, J., concurring in the judgment only) ("Quite simply, the Establishment Clause is best understood as a federalism provision-it protects state establishments from federal interference but does not protect any individual right. These two features independently make incorporation of the Clause difficult to understand."); see also Josh Blackman \& Ilya Shapiro, Keeping Pandora's Box 


\section{Economic Liberty}

Harlan's lectures also foreshadowed the views he expressed in his lesser known, but more moderate dissent in Lochner v. New York. ${ }^{436}$ Harkening back to his namesake Chief Justice John Marshall's eternal maxim in Marbury v. Madison- "It is emphatically the province and duty of the judicial department to say what the law is"437-Harlan explained that "[t]he judiciary does not make laws, it declares them."438

Recognizing the role that the government plays to protect society from the threats of then-modern day industrialization, Harlan reminded his students:

[T] he safety of this country today, the safety of our institutions today, lies mainly in the fact that the judiciary of this land restricts the exercise of its powers to the declaration of what the law is, and not assume unnecessarily to pass in judgment upon the wisdom of legislation..$^{439}$

In Lochner, Harlan made much the same point about the Court's concern about the "wisdom" of legislation: "Whether or not this be wise legislation it is not the province of the court to inquire. Under our systems of government the courts are not concerned with the wisdom or policy of legislation." ${ }_{440}$

Harlan also set out for his students the framework he adopted in Lochner for purposes of reviewing an economic regulation:

You have the exclusive right to use it, but when you take it into a particular state, you are subject to the laws of that state, and the state may say it is not reasonable that it should be used, and if it is a reasonable law, it is bound to be respected. ${ }^{441}$

More explicitly, Harlan stated, "Now, the Supreme Court of the United States long ago said, and that is the rule of the courts of all the

Sealed: Privileges or Immunities, The Constitution in 2020, and Properly Extending the Right to Keep and Bear Arms to the States, 8 Geo. J. L. \& PuB. PoL'Y 1, 65 (2010) (discussing the Establishment Clause); Alan Gura, Ilya Shapiro, \& Josh Blackman, The Tell-Tale Privileges or Immunities Clause, 2010 Cato Sup. CT. Rev. 163, 192 (discussing application of the Privileges or Immunities Clause to the protection of constitutionally enumerated rights).

436 Lochner v. New York, 198 U.S. 45, 65 (1905) (Harlan, J., dissenting). For a history of Lochner, see generally David E. Bernstein, Rehabilitating Lochner: Defending Individual Rights Against Progressive Reform (2011).

437 Marbury v. Madison, 5 U.S. (1 Cranch) 137, 177 (1803).

438 See Justice Harlan's Lectures, supra note 1, at 108 (Lecture No. 9, Dec. 11, 1897).

439 Id. (emphasis added).

440 Lochner, 198 U.S. at 69 (Harlan, J., dissenting).

441 Justice Harlan's Lectures, supra note 1, at 141 (Lecture No. 12, Jan. 16, 1898) (referring to state regulations regarding sale of patented oil). 
states, that no court shall strike down an act of legislation as unconstitutional and void unless it is clearly so; unless it is palpably so." 442

His dissent in Lochner tracks this quotation, almost exactly, with a focus on palpable unconstitutionality: "Upon this point there is no room for dispute, for, the rule is universal that a legislative enactment, Federal or state, is never to be disregarded or held invalid unless it be, beyond question, plainly and palpably in excess of legislative power." 443 The statements are nearly identical. Harlan was comfortable with the exercise of judicial review, so long as the courts were not second-guessing the wisdom of legislators, who had a duty to protect and safeguard society. 444 His lecture follows, almost verbatim, his dissent in Lochner seven years later.

Similarly, Justice Harlan's view of the Contracts Clause ${ }^{445}$ was laid out to his class in clear terms:

Now, this injunction is that that obligation shall not be impaired. Not impaired a little, not impaired much, but shall not be impaired at all. It must stand as the parties have made it. If it was lawful when made, it is not in the power of any state to make it unlawful. ${ }^{446}$

In Home Building \& Loan Ass'n v. Blaisdell, ${ }^{447}$ however, the Court rejected Harlan's position, holding that a law "impairs" a contract only if it renders the contract unenforceable. ${ }^{448}$

\section{Suffrage and Gender Equality}

Harlan lectured more than a decade before the ratification of the Nineteenth Amendment, which prevented the denial of the vote to women.449 His lectures are consistent with the contemporary views that neither the Fourteenth nor Fifteenth Amendment accomplished this goal:

442 Id. at 161 (Lecture No. 13, Jan. 22, 1898) (emphasis added).

443 Lochner, 198 U.S. at 68 (emphasis added) (Harlan, J., dissenting).

444 See id. at 69.

445 U.S. Const. art. I, § 10, cl. 1 ("No State shall ...pass any ... Law impairing the Obligation of Contracts ....").

446 Justice Harlan's Lectures, supra note 1, at 185 (Lecture No. 15, Feb. 15, 1898).

447 Home Bldg. \& Loan Ass'n v. Blaisdell, 290 U.S. 398 (1934).

448 Id. at 431 ("The obligations of a contract are impaired by a law which renders them invalid, or releases or extinguishes them and impairment, as above noted, has been predicated of laws which without destroying contracts derogate from substantial contractual rights.") (citation and footnote omitted).

449 U.S. Const, amend. XIX (ratified in 1920). 
Then there often occurs the question, may a state discriminate against a woman on account of her sex, as far as her right to vote is concerned? Yes, [the Fifteenth Amendment] only says "that the right to vote shall not be abridged on account of race, color, or previous condition of servitude." The word sex is not there. ${ }^{450}$

According to Harlan, there was nothing in the Constitution (at that time) that prohibited a state from discriminating against women, even when it came to the right to vote. ${ }^{451}$

Still, Harlan, ever the textualist, had no problem with a woman being able to serve as President, as the qualifications in Article II have no limitations based on gender-even if the woman candidate could not vote for herself! "I am asked the question whether or not a woman can be President of the United States. Yes, if the men are willing that this should occur, she may." ${ }^{452}$ All of Harlan's students were male, and it is unclear how he would have viewed the prospect of a female lawyer. When discussing the case or controversy requirement of Article III, Harlan quipped:

You will meet with people who seem to labor under the impression that it is competent for the courts of the United States to meet every possible case that may arise in a court of justice, and particularly if you meet with one of our friends of the gentler sex who has just come to the conclusion that she ought to be a lawyer. She [does not] understand why it is that the courts of the United States cannot dispose of every case and every question that involves the general welfare. It is hard to explain it, equally hard to explain it to a man who [does not] stop to think, and who [does not] read the words of this Constitution. ${ }^{453}$

450 Justice Harlan's Lectures, supra note 1, at 346 (Lecture No. 27, May 7, 1898) (quoting U.S. Const, amend. XV).

451 Id. But see Craig v. Boren, 429 U.S. 190, 191-92, 210 (1976) (finding that gender-differentiated purchasing ages for low-alcohol beer violated the Equal Protection Clause). The Court's holding in Craig leads to the conclusion that gender and, a fortiori, race-based discrimination in voting rights should have been considered egregious violations of the Equal Protection Clause, rendering the Fifteenth and Nineteenth Amendments entirely superfluous, at least with regard to their applicability to the states. It may well be the case that Justice Harlan's interpretation of the scope of equal protection was informed by the fact that the Fifteenth Amendment was not needed at all, which would also logically lead him to the textual conclusion referred to above. For more on the original understanding of the Fourteenth Amendment with respect to women's suffrage, see generally Josh Blackman, Originalism at the Right Time?, 90 TEx. L. REv. SEE Also 269 (2012).

452 Justice Harlan's Lectures, supra note 1, at 346 (Lecture No. 27, May 7, 1898).

453 Id. at 244-45 (emphasis added). 


\section{Harlan the Seer}

When Harlan delivered his lectures, the Constitution was undergoing a process of transformation. Today, though the Court has adopted many of Harlan's conclusions, it has not necessarily adopted his reasons. While modern reformers find many of Harlan's conclusions congenial, they may find his reasoning less palatable. Their Constitution reflects the idealist assumptions of a liberal future. Harlan's Constitution reflects the traditional principles of a republican past. And yet, the conundrum remains: somehow Harlan managed to simultaneously look backward and anticipate modern civil liberties, even as his forward-looking brethren foundered. The reason is both simple and critical-judges and lawyers can make laws, but they cannot make a constitution. Harlan did not merely anticipate the future Constitution. He created it. Much as the colonial Americans created a liberal revolution out of a mythological past, Harlan created a liberal Constitution out of traditional rights. Thus, by understanding Harlan, we come to understand not just how the Constitution works in the present, but how it comes to transform the future.

Harlan's prescient opinions were well ahead of his time. In his classroom, he provided his students with insights into how constitutional law would develop well into the twentieth century, with respect to the doctrine of incorporation, the scope of Congress's powers under the commerce clause, the Erie doctrine and vertical comity, and the evolution of separation of powers.

\section{A. Incorporation}

At the time of their ratification, the first ten amendments to the Constitution were not a true bill of rights, because they limited only the powers of the federal government to infringe on individual liberty, not those of the states. ${ }^{454}$ Only a state constitution could contain a bill of rights declaring the rights of an individual. ${ }^{455}$ The Fourteenth Amendment created the Bill of Rights as we know it today. ${ }^{456}$ But with the Fourteenth Amendment, judges gradually began to tell a new constitutional story, emphasizing national, individual rights. Harlan recognized that "one of the largest questions before the courts of this country yet to determine ... is what rights are secured against state action by this clause of the Fourteenth Amendment." 457 At the time

\footnotetext{
454 See Akhil Reed Amar, The Bill of Rights 284-85 (1998).

455 See id.

456 See id.; U.S. ConsT. amend. XIV.

457 Justice Harlan's Lectures, supra note 1, at 251 (Lecture No. 20, Mar. 12, 1898).
} 
on the Court, Harlan alone argued that the Fourteenth Amendment incorporates the Bill of Rights against the states. ${ }^{458}$ The first reference to selective incorporation appears in Justice Harlan's dissent in Hurtado v. California, ${ }^{459}$ where Harlan would have found the right to a grand jury indictment was required in state prosecutions. ${ }^{460}$ History would vindicate Harlan's view that the Bill of Rights applies to the states.

\section{Harlan's Prescient Opinions}

Although Harlan's dissent in Hurtado seems to advocate selective incorporation, his discussion is somewhat vague. ${ }^{461}$ According to Professor Jerold Israel, "Justice Harlan's dissent . . . arguably also may be viewed as based on a selective incorporation theory, but his analysis is ambiguous and the opinion might be urging total incorporation." 462 Israel claims, "Justice Harlan's dissent, although focusing on the history and importance of the grand jury, suggested at one point that a right might be established as an essential element of due process solely by virtue of its inclusion in the Bill of Rights." $" 463 \mathrm{He}$ adds that the "reasoning, of course, would have led to incorporation of all of the Bill of Rights as part of due process." 464

Harlan's dissent implied an incorporation doctrine without explicitly naming one or agreeing with it. In fact, Harlan employed the term "incorporation" just twice. The first reference has to do with the colonists' incorporation of English common law: "These declarations were subsequently emphasized in the most imposing manner, when the doctrines of the common law respecting the protection of the people in their lives, liberties, and property were incorporated into the earlier constitutions of the original States." ${ }_{465}$

Harlan's opinion in Chicago Burlington \& Quincy R.R. v. Chicago, ${ }^{466}$ decided one year before his lecture on March 1, 1897, extended the Takings Clause-somewhat obliquely-to the states. ${ }^{467}$

458 See id.

459 Hurtado v. California, 110 U.S. 516, 540-41 (1884) (Harlan, J., dissenting).

460 Id.

461 Id.

462 Jerold H. Israel, Selective Incorporation: Revisited, 71 GEo. L.J. 253, 253 n.1 (1982).

463 Id. at 279 n.188.

$464 I d$.

465 Hurtado v. California, 110 U.S. 516, 540 (1884) (Harlan, J. dissenting) (emphasis added).

466 Chicago, Burlington \& Quincy R.R. Co. v. Chicago, 166 U.S. 226 (1897).

467 Id. at 241. 
This 1897 precedent predating the modern incorporation doctrine did not incorporate the Fifth Amendment, but rather considered the taking as a violation of due process. ${ }^{468}$ A century later, in Palazzolo $v$. Rhode Island, ${ }^{469}$ citing Chicago Burlington \& Quincy R.R., the Supreme Court held that the "Takings Clause of the Fifth Amendment, applicable to the States through the Fourteenth Amendment prohibits the government from taking private property for public use without just compensation." ${ }^{470}$ Harlan was one hundred years ahead of his time.

\section{Grand Jury Clause}

The Grand Jury Clause ${ }^{471}$ was a recurring theme in Justice Harlan's lectures. Today, many people consider the grand jury a quaint relic. In most jurisdictions, it provides no protection against unjust prosecution, because a grand jury will "indict a ham sandwich." ${ }^{472}$ Virtually every Justice has asked whether fundamental fairness requires a grand jury. Not Harlan. He insisted that the Constitution, as modified by the Fourteenth Amendment, requires indictment by a grand jury in all criminal cases, simply because the common law required a grand jury: "My own view," Harlan lectured, "was that it was not competent for a state, since the adoption of the Fourteenth Amendment, to proceed against any man for his life except by indictment of a grand jury." 473

Much to his obvious dismay, the Court did not share his view of the importance of the clause. Harlan added in class, "Now presumably I am wrong, because I stood alone, and the law must be held otherwise." 474 The case of Hurtado $v$. California repeatedly revealed his less-than-lighthearted disagreement with some recent precedent. ${ }^{475}$ The lack of levity was especially striking on the evening of March 12, 1898, when Justice Harlan flatly said, "I can add nothing tonight to what I said in that opinion." 476 Harlan recognized that by nationaliz-

$468 I d$.

469 Palazzolo v. Rhode Island, 533 U.S. 606 (2001).

$470 I d$. at 617 (citation omitted).

471 U.S. Const. amend. V.

472 Marcia Kramer \& Frank Lombardi, New Top State Judge: Abolish Grand Juries \& Let Us Decide, N.Y. Daily News, Jan. 31, 1985, at 3 (quoting Judge Sol Wachtler).

473 Justice Harlan's Lectures, supra note 1, at 310 (Lecture No. 24, Apr. 16, 1898); see also Hurtado v. California, 110 U.S. 516, 538-58 (Harlan, J., dissenting).

474 Justice Harlan's Lectures, supra note 1, at 310 (Lecture No. 24, Apr. 16, 1898).

475 See id. at 252-53 (Lecture No. 20, Mar. 12, 1898); id. at 310 (Lecture No. 24, Apr. 16, 1898); id. at 312 (Lecture No. 25, Apr. 23, 1898).

476 Id. at 253 (Lecture No. 20, Mar. 12, 1898) (referring to Hurtado, 110 U.S. at 538-58 
ing individual rights, the Fourteenth Amendment rendered the Barron v. Baltimore ${ }^{477}$ status quo untenable. Against those who criticized federal intervention in state laws, Harlan declared, "there is no provision in the Federal Constitution to which we should cling harder than the Fourteenth Amendment." ${ }^{478}$ Harlan made no joke about his being in dissent in this case.

\section{Right to Jury Trial}

Harlan felt similarly about the Petit Jury Clause. ${ }^{479}$ To Harlan, the significance of the right to trial by jury stretched back to the Magna Carta: "We have preserved in our fundamental law this right of trial by jury." ${ }^{80}$ According to Harlan, "there is no feature of our Anglo-Saxon civilization today that lies more nearly to the liberty of man than the right of a trial by the old-fashioned jury composed of twelve honest men." 481 He began by arguing that judges appointed on good behavior are more independent than elected judges. ${ }^{482}$ He then tied the jury trial guarantee to the Due Process Clause of the Fourteenth Amendment, which he believed extends this same right to apply against the states. ${ }^{483}$ Thus, for Harlan, due process of law did not mean fairness, but rigorous adherence to traditional procedures. $\mathrm{He}$ continued with a discussion of the Treason Clause, using Justice Marshall's conduct during the trial of Aaron Burr as an example of how appointed judges preserve constitutional principles in the face of mercurial popular sentiment. ${ }^{484}$

Harlan felt strongly about the right to a jury trial:

So, along in that line of cases is the large question, not yet concluded, that as to whether a state may dispense with a petit jury or modify the trial as it was at the time of the adop-

(1884) (Harlan, J., dissenting)). Justice Harlan displayed similar impatience when remarking briefly on the cases of Pollock v. Farmers' Loan \& Trust Co., 158 U.S. 601, 638-86 (1895) (Harlan, J., dissenting) (income taxation), and Elk v. Wilkins, 112 U.S. 94, 110-23 (1884) (Harlan, J., dissenting) (Native American citizenship). See Justice Harlan's Lectures, supra note 1, at 176-77 (Lecture 15, Feb. 5, 1898); id. at 265 (Lecture 21, Mar. 19, 1898). Following McDonald v. City of Chicago, 130 S. Ct. 3020 (2010), the Supreme Court has declined to consider any cases that would require the incorporation of the Grand Jury Clause. See infra notes 498-500 and accompanying text.

477 Barron v. Baltimore, 32 U.S. (7 Pet.) 243 (1833).

478 Justice Harlan's Lectures, supra note 1, at 345 (Lecture No. 27, May 7, 1898).

479 U.S. Const. art. III, § 2, cl. 3.

480 Justice Harlan's Lectures, supra note 1, at 24 (Lecture No. 2, Oct. 21, 1897).

481 Id. at 250 (Lecture No. 20, Mar. 12, 1898).

482 See id. at 243-44.

483 Id. at 251-52.

484 Id. at 253-55. 
tion of the Constitution? I answer unhesitatingly that no court of the United States can try a man for any crime by a jury less than twelve, or can sentence any man upon the return of a verdict of jury in which all the jury have not concurred. 485

It should be noted that the phrase "court of the United States" all but certainly means both federal and state courts. The context bears this out, even if the language used today commonly connotes only federal courts. ${ }^{486}$ While the Supreme Court has found that the right to a jury trial is incorporated against the states, ${ }^{487}$ the Court has also held that a jury of less than twelve is constitutionally permissible. ${ }^{488}$ Most recently, the Supreme Court declined to review ${ }^{489}$ a challenge to Apodaca $v$. Oregon, ${ }^{490}$ which had held-in a fractured, confusing opinion-that a defendant could be convicted by a less than unanimous jury verdict. ${ }^{491}$

\section{Eighth Amendment Prohibition Against Cruel and Unusual Punishment}

Harlan also believed that the protections of the Eighth Amendment should apply to the states. After the ratification of the Fourteenth Amendment, States could no longer inflict cruel and unusual punishments on their prisoners:

That clause [of the Eighth Amendment] did not stand in the way of any state imposing a cruel and unusual punishment. But now the Fourteenth Amendment says that no state shall deprive any man of life, liberty, or property without due process of law. Suppose a state today should pass a law introducing the punishments of torture, a law which would authorize some ministerial officer to put a man to torture in

$485 I d$. at 252.

486 See id.

487 Duncan v. Louisiana, 391 U.S. 145, 156 (1968).

488 Williams v. Florida, 399 U.S. 78, 102-03 (1970).

489 State v. Herrera, 14 P.3d 102 (Or. Ct. App. 2000), cert. denied, 131 S. Ct. 904 (2011). See generally Petition for Writ of Certiorari, Herrara, 131 S.Ct. 904 (No. 10-344) (urging the Supreme Court to decline to follow the fractured decision of Apodaca v, Oregon, 406 U.S. 404 (1972), in which no rationale received five votes).

490 Apodaca v. Oregon, 406 U.S. 404 (1972).

491 See id. at 411 ("In terms of this function we perceive no difference between juries required to act unanimously and those permitted to convict or acquit by votes of 10 to two or 11 to one. Requiring unanimity would obviously produce hung juries in some situations where nonunanimous juries will convict or acquit. But in either case, the interest of the defendant in having the judgment of his peers interposed between himself and the officers of the State who prosecute and judge him is equally well served.") (plurality opinion) (footnote omitted). 
order to make him confess before he was tried. Or suppose it provided the punishment of burning a man at the stake if he was convicted of a particular crime. Is that due process of law? Is the state prohibited from resorting to any mode of punishment of that sort? ${ }^{492}$

To Harlan, among the liberties protected by the Due Process Clause of the Fourteenth Amendment was the right to be free from cruel and unusual punishment. This conception of what we now call incorporation was an early incarnation of the notion of substantive due process. The Supreme Court ultimately adopted this position in Robinson v. California. ${ }^{493}$

\section{Incorporation in the Twentieth Century}

For much of the early twentieth century, the Supreme Court had difficulty coming to grips with how rights in the first eight Amendments to the Constitution should be extended to the states. ${ }^{494}$ In 1947, Justice Frankfurter dismissed Harlan's argument that the Fourteenth Amendment incorporated the Bill of Rights in its entirety, referring to him as the "only" Justice to hold that view, and "respectfully" calling him "an eccentric exception." 495 In a sense, Frankfurter was right. For Frankfurter, as for many other justices, "safeguarding and promoting the interests of liberty and human dignity through law" required only attentiveness to fundamental fairness, not zealous preservation of procedural safeguards. ${ }^{496}$ Perhaps Frankfurter was right to see many of the common law rights on which Harlan insisted as "the restricted views of Eighteenth-Century England regarding the best methods for the ascertainment of facts." 497

The Court to this day still has not settled on a single approach to the incorporation of rights. Justice Thomas has even declared that the entirety of the twentieth's century incorporation jurisprudence through the due process clause was flawed; rather, the Privileges or Immunities Clause is the appropriate channel. ${ }^{498}$ A century earlier,

492 Justice Harlan's Lectures, supra note 1, at 252 (Lecture No. 20, Mar. 12, 1898).

493 Robinson v. California, 370 U.S. 660, 667 (1962).

494 See Duncan v. Louisana, 391 U.S. 145 (1968); Malloy v. Hogan, 378 U.S. 1, (1964); Adamson v. California, 332 U.S. 46 (1947); Palko v. Connecticut, 302 U.S. 319 (1937).

495 See Adamson, 332 U.S. at 62 (Frankfurter, J., concurring).

496 See id.

497 See id. at 63.

498 See, e.g., McDonald v. City of Chicago, 130 S. Ct. 3020, 3083-84 (2010) (Thomas, J., concurring) (finding that the right to keep and bear arms is a privilege under the Privileges or Immunities Clause). For further reading on the Privileges or Immunities Clause as it relates to the right to keep and bear arms, see generally Gura, Shapiro \& Blackman, supra note 435. For a 
Harlan briefly mentioned the Privileges or Immunities Clause of the Fourteenth Amendment, not enumerating the rights it guarantees, but specifying that a person may appeal their abrogation by a state:

$[\mathrm{T}]$ he question arises whether or not these privileges in the first ten amendments are not privileges pertaining to citizenship of the United States, and is it now, since the adoption of the Fourteenth Amendment, in the power of any state to take away from anyone the privileges conferred by those amendments. ${ }^{499}$

History refutes Frankfurter's flippant aside, as the Court has incrementally incorporated nearly every provision of the Bill of Rights, with the exception of Harlan's cherished Grand Jury Clause. To this day, the grand jury right is one of the few provisions in the Bill of Rights not incorporated against the states. In fact, during oral arguments in McDonald v. City of Chicago-which considered whether the right to keep and bear arms should be extended to the states-two Justices asked about the implications of the Grand Jury Clause not being incorporated. ${ }^{500}$ Ultimately, Harlan's supposed anachronismnot Frankfurter's realism-made it possible for the Constitution to guarantee modern civil rights. Frankfurter described reality, but Harlan, a half century earlier, transformed it. If Harlan was an "eccentric exception," exceptionalism is the key to the American national myth.

\section{B. The Commerce Clause}

The scope of Congress's power under the Commerce Clause stands today as one of the most hotly debated questions of constitutional law. Over a hundred years ago, Harlan recognized how important this provision would become. Harlan wisely instructed his students-many of whom would later become the officials administering the New Deal and defending it in court-to pay close attention to the Commerce Clause:

detailed account of McDonald $\nu$. City of Chicago, see generally Blackman \& Shapiro, supra note 435.

499 Justice Harlan's Lectures, supra note 1, at 309 (Lecture No. 24, Apr. 16, 1898).

500 Justices Sotomayor and Ginsburg expressed concern that if the right to keep and bear arms was incorporated, states would also need to provide indictments by grand juries. Transcript of Oral Argument at 4, 62-63, McDonald v. City of Chicago, 130 S. Ct. 3020 (2010) (No. 081521), available at http://www.oyez.org/cases/2000-2009/2009/2009_08_1521 (Justice Sotomayor: "What injustice has-has been caused by it that we have to remedy? Meaning States have relied on having no grand juries . . . ."; Justice Ginsburg: "So you are saying that under-under your view, every State would have to use a grand jury to bring criminal charges; no more information."). 
Now, there is a line of decisions in this country that you ought to become familiar with on that subject, for I can state to you with entire confidence that when you get to the bar and have a good practice in your profession, and you become connected with cases involving constitutional law, probably the most important you will have are those connected with the commerce of the country. ${ }^{501}$

To Harlan, commerce wholly within one state could not be interstate commerce:

There is a commerce with which the United States has nothing to do, the power to control which has never been granted to the United States. Take commerce between the City of New York and the City of Rochester, New York, for instance, or commerce between Alexandria and the City of Richmond, Virginia, or commerce between the City of Cincinnati and Columbus, Ohio. That is purely domestic. That commerce commences in a state and ends in the same state. $^{.02}$

Harlan recognized that matters solely within the province of the state were not the business of the federal government:

[T] he government of the United States has no more to do with it than it has with the commerce in the interior of China. The states have never granted to the government of the United States the power to control those things, and it is well that they have not. If the power to control the internal domestic trade of the states belonged to the government of the United States, there would be foundation for the apprehension of some that all powers of localities and municipalities in this country would be lost sight of in a vast centralized government, and the men who framed this Constitution were wise in the thought that there were many things that could not be controlled by the United States. ${ }^{503}$

Harlan's apprehensions-that the powers of the states would be lost amidst the "vast centralized government"-proved prudent, as the scope of an unlimited commerce power is of the utmost importance today at the Supreme Court.

However, Harlan lamented the difficulty of the national government addressing problems of local nature:

501 Justice Harlan's Lectures, supra note 1, at 121 (Lecture No. 10, Dec. 18, 1897) (emphasis added).

502 Id. at 117.

503 Id. 
I am speaking of the difficulty in our present system of getting proper attention to matters that concern the nation. What would we do if all these merely local affairs that belong now exclusively to the states were under the control of the Congress of the United States, simply because you call it commerce? No, the kind of commerce which Congress can regulate is commerce with foreign nations, and among the several states, that is commerce between the states. ${ }^{504}$

Yet, Harlan realized that the society of the future may not comport with how the Constitution was understood at the time of its adoption.

When that Constitution was adopted, no man of that day had the slightest idea that he would be able to start from the City of New York in the morning at ten o'clock and find himself in Chicago the next day at nine o'clock. The commerce that was then thought of was commerce on water, commerce on navigable waters; the commerce between the City of New York, for instance, and Savannah, Georgia, by the ocean; commerce from the City of New York to Philadelphia, partly by ocean and partly by Delaware River. Nobody ever thought then of steam railways, and yet it is practically well settled at this day, and settled some while back, that that provision of the Constitution of the United States embraces commerce across the country by railroad as well as commerce upon the navigable waters of the United States. ${ }^{505}$

Harlan, with his eyes to the future, inspired his students to think of how the evolution of technology would further revolutionize the nature of interstate commerce.

And that suggests a line of thought that no doubt has occurred to you. It suggests a subject about which the public mind of this country is very much divided today, and so much divided that no statesman is able to speak with very great confidence as to what can be, or ought to be done. If, as undoubtedly is the fact, commerce between the City of New York and the City of San Francisco across lines of railway is commerce, that may be regulated by the United States. What shall be the extent of regulation that the government of the United States will undertake? How far will it go? ${ }^{506}$ 
Harlan, who was lecturing on the precipice of the Industrial Revolution, looked ahead a century at what would soon be an explosion in the need for Congress to regulate commerce and trade among the several states:

What would we do if all these merely local affairs that belong now exclusively to the states were under the control of the Congress of the United States simply because you call it commerce?

Now, the difficult question that cannot be solved by any rule today that would be applicable a hundred years from now is, what may be done under the power to regulate commerce with foreign nations and among the several states? ${ }^{507}$

Echoing modern constitutional debates, the pressing question for Harlan was what would be the limiting principle of Congress's powers if everything is considered interstate commerce?

Harlan later expressed these views in the Lottery Case, ${ }^{508}$ where the Court held that trafficking lottery tickets constituted interstate commerce, and Congress could regulate it. ${ }^{509}$ As fate would have it, Harlan now seems somewhat clairvoyant in his fears. ${ }^{510}$ Harlan was quite cognizant of the import of the Commerce Clause:

Now, these questions thus suggested will indicate to you what vast power lurks under that clause of the Constitution of the United States, but as vast as that power is, and whatever may be the dangers that are to come from its exercise, it had better be there; it had better rest with the government of the United States than to rest with each state as to what shall be charged for the transportation of persons and freight across that state. ${ }^{511}$

507 Id. at 118 (emphasis added).

508 Champion v. Ames (The Lottery Case), 188 U.S. 321 (1903).

509 Id. at 363-64.

510 See, e.g., Gonzales v. Raich, 545 U.S. 1, 18 (2005) ("Congress can regulate purely intrastate activity that is not itself 'commercial,' in that it is not produced for sale, if it concludes that failure to regulate that class of activity would undercut the regulation of the interstate market in that commodity."); Wickard v. Filburn, 317 U.S. 111, 125 (1942) ("But even if appellee's activity be local and though it may not be regarded as commerce, it may still, whatever its nature, be reached by Congress if it exerts a substantial economic effect on interstate commerce, and this irrespective of whether such effect is what might at some earlier time have been defined as 'direct' or 'indirect." ").

511 Justice Harlan's Lectures, supra note 1, at 121 (Lecture No. 10, Dec. 18, 1897). 
To this day, the Supreme Court still has not come to a conclusion about the scope of that "vast power." 512

\section{The Erie Doctrine and Vertical Comity}

Harlan's discussion on the legitimacy of federal common law and the importance of vertical comity in federalism eerily foreshadows the Erie doctrine some forty years before it was created. In a lecture on January 29, 1898, almost fifty-six years to the day after Swift v. Tyson $^{513}$ was decided, Justice Harlan offered his students this lesson on the role of federal courts and the common law:

Do not get that idea in your heads, that the courts of the United States are courts of a foreign government. A judge of the court of the United States, sitting in the State of New York, sits there to administer in part-and that is the most that he does-the laws of the State of New York, the court getting jurisdiction by reason of diverse citizenship. And a federal court sitting in the State of New York is in every sense a court of the State of New York, and the Supreme Court of the United States is a court for all the states and all the people of all the states. ${ }^{514}$

Contrast that statement with then-prevailing law from Swift $v$. Tyson's holding that the federal courts developed a common law distinct from the law of the state. ${ }^{515}$ Now fast-forward forty years to Erie Railroad v. Tompkins ${ }^{516}$ :

Except in matters governed by the Federal Constitution or by Acts of Congress, the law to be applied in any case is the law of the State. And whether the law of the State shall be declared by its Legislature in a statute or by its highest court in a decision is not a matter of federal concern. There is no federal general common law. Congress has no power to declare substantive rules of common law applicable in a State whether they be local in their nature or "general," be they commercial law or a part of the law of torts. And no clause

512 See generally Nat'l Fed'n of Indep. Bus. v. Sebelius, 132 S. Ct. 2568 (2012). For further reading on the Health Care Cases, see Josh Blackman, Unprecedented: The Constitu. tional Challenge to ObamaCare (2013); Josh Blackman, Back to the Future of Originalism, 16 Chapman L. Rev. 325 (2013); Josh Blackman, Popular Constitutionalism and the Affordable Care Act, 26 PuB. AFF. Q. (forthcoming 2013), available at http://papers.ssrn.com/sol3/papers. cfm?abstract_id=2217965.

513 Swift v. Tyson, 41 U.S. (16 Pet.) 1 (1842).

514 Justice Harlan's Lectures, supra note 1, at 172-73 (Lecture No. 14, Jan. 29, 1898).

515 Swift, 41 U.S. (16 Pet.) at 18-19.

516 Erie R.R. v. Tompkins, 304 U.S. 64 (1938). 
in the Constitution purports to confer such a power upon the federal courts. ${ }^{517}$

After discussing the uncontroversial proposition that the Supreme Court of the United States has jurisdiction to review the final judgments of state courts, ${ }^{518}$ Justice Harlan quickly dispelled any notion that state courts possess any such reciprocal authority. He explained that a state may not issue a writ of habeas corpus to federal authorities:

Now that was Tarble's case in 13th Wallace, and there it was settled that the state authorities could not disturb the United States authorities. Why the difference? One reason of the difference is-and that is an all-sufficient one-that one is the supreme government of the country, the highest government of the country. ${ }^{519}$

In this sense, Justice Harlan's views presaged the slow demise of Swift $v$. Tyson, and the ultimate repudiation of federal common law in 1938.

Likewise, ten years before the Court decided Ex Parte Young, ${ }^{520}$ Justice Harlan grudgingly predicted-or perhaps conceded-the outcome: "Now, it has been held time and again that a suit against an officer of a state to prevent him from executing an unconstitutional law of that state is not a suit against the state, and that it can be instituted." ${ }_{221}$ While Harlan dissented in Ex Parte Young a decade later, arguing that such a suit should not be permitted, perhaps he realized that it was inevitable. ${ }^{522}$ Harlan recognized the evolution of Erie and vertical comity well before his time.

517 Id. at 78 (emphasis added).

518 Justice Harlan's Lectures, supra note 1, at 172 (Lecture No. 14, Jan. 29, 1898) (citing Martin v. Hunter's Lessee, 14 U.S. (1 Wheat.) 304 (1816)).

519 Id. (citing Tarble's Case, 80 U.S. (13 Wall.) 397 (1871)).

s20 Ex parte Young, 209 U.S. 123 (1908).

521 Justice Harlan's Lectures, supra note 1, at 338 (Lecture No. 26, Apr. 30, 1898).

522 Ex parte Young, 209 U.S. at 175-76 (Harlan, J., dissenting) ("This principle, if firmly established, would work a radical change in our governmental system. It would inaugurate a new era in the American judicial system and in the relations of the National and state governments. It would enable the subordinate Federal courts to supervise and control the official action of the States as if they were 'dependencies' or provinces. It would place the States of the Union in a condition of inferiority never dreamed of when the Constitution was adopted or when the Eleventh Amendment was made a part of the Supreme Law of the Land. I cannot suppose that the great men who framed the Constitution ever thought the time would come when a subordinate Federal court, having no power to compel a State, in its corporate capacity, to appear before it as a litigant, would yet assume to deprive a State of the right to be represented in its own courts by its regular law officer."). 


\section{Separation of Powers}

To Harlan, one of the most unique aspects of our system of government was the separation of powers, both between the three branches, as well as between the states and the federal government. Harlan's discussions about setting the qualifications of representatives, Congress choosing their own rules, bicameralism and presentment, and appointment of executive branch officials presaged many of the larger separation of powers conflicts in the twentieth century.

\section{Qualifications of Representatives}

In all of the Constitution's provisions which may arguably enshrine some principle of federalism, perhaps the most unassuming provides that " $[t]$ he Times, Places and Manner of holding Elections for Senators and Representatives, shall be prescribed in each State by the Legislature thereof; but the Congress may at any time by Law make or alter such Regulations, except as to the Places of chusing Senators." 523 Of that clause, Justice Harlan lectured, "There is no more important provision in the Constitution than that, nor one about which there is a larger amount of ignorance, or none about which more unmeaning or senseless things are said." 524

Though Harlan was, at times, prone to hyperbole, his point should not be lost on us today. During his lecture on November 20 , 1897, Justice Harlan took the opportunity to opine on the role of the states in defining the national identity in our federalist framework:

We must not forget that a member of the House of Representatives is not there simply as the representative of the people of his district. He represents in a sense the whole country ....

It is not to be entertained for a moment that any state of this union can act as it pleases in the matter of sending Representatives to Congress beyond the power of the United States. ${ }^{525}$

This theory of who members of Congress in fact represent, has been the subject of much scholarly debate. ${ }^{526}$ It would be nearly a

523 U.S. Const. art. I, § 4, cl. 1. The second clause, less consequentially, merely provides that " $[t]$ he Congress shall assemble at least once in every Year, and such Meeting shall be on the first Monday in December, unless they shall by Law appoint a different Day." U.S. CoNST. art I, $\S 4$, cl. 2 (emphasis denotes portion of the clause modified by U.S. ConsT. amend. XX).

524 Justice Harlan's Lectures, supra note 1, at 78 (Lecture No. 7, Nov. 20, 1897).

525 Id. at 78-79.

526 See generally Brief for the United States as Amicus Curiae Supporting Respondents, U.S. Term Limits, Inc. v. Thornton, 514 U.S. 779 (1995) (No. 93-1456). 
century, however, before the Supreme Court weighed in on the precise issue in any definitive way.

The Court in U.S. Term Limits, Inc. v. Thornton, ${ }^{527}$ per Justice Stevens, held that the imposition of term limits for Congressional candidates by Arkansas was not a regulation of the time, place, or manner of choosing representatives, but rather an impermissible restriction on the qualifications for that office. ${ }^{528}$ In so doing, the Court noted that in our federal government, "representatives owe primary allegiance not to the people of a State, but to the people of the Nation." "529 Stressing the significance of this issue, Justice Scalia said, "This is the most important federalism case that has been heard during my time on the bench." 530 Moderating the 5-4 ruling, as usual, was Justice Kennedy. ${ }^{531}$ Echoing the views of Justice Harlan, a century earlier, ${ }^{532}$ Justice Kennedy forcefully stated, "That the States may not invade the sphere of federal sovereignty is as incontestable, in my view, as the corollary proposition that the Federal Government must be held within the boundaries of its own power when it intrudes upon

527 U.S. Term Limits, Inc. v. Thornton, 514 U.S. 779 (1995).

528 Id. at $829-30$.

529 Id. at 803 (quoting 1 STORY, supra note 164, § 627) (further commenting that "each Member of Congress is 'an officer of the union, deriving his powers and qualifications from the constitution, and neither created by, dependent upon, nor controllable by, the states . . . Those officers owe their existence and functions to the united voice of the whole, not of a portion, of the people.'"); see also 2 STORY, supra note $164, \S 626$.

530 Jerry de Jaager, Justice Scalia Comes Home to the Law School, RECORD, Spring 2012, available at http:/www.law.uchicago.edu/alumni/magazine/spring12/scalia.

531 See Term Limits, 514 U.S. at 838-45 (Kennedy, J., concurring). Kennedy began his opinion with a conciliatory nod to the dissenters-Justice Thomas's opinion was joined by the Chief Justice and Justices O'Connor and Scalia- "The majority and dissenting opinions demonstrate the intricacy of the question whether or not the Qualifications Clauses are exclusive." Id. at 838 .

532 Term Limits, 514 U.S. at 841-42 (Kennedy, J, concurring). Though he joined the opinion of the Court in full, Kennedy's concurring opinion developed a slightly more nuanced view of the theoretical federalism at play in the case:

The political identity of the entire people of the Union is reinforced by the proposition, which I take to be beyond dispute, that, though limited as to its objects, the National Government is, and must be, controlled by the people without collateral interference by the States. McCulloch affirmed this proposition as well, when the Court rejected the suggestion that States could interfere with federal powers. "This was not intended by the American people. They did not design to make their government dependent on the States." The States have no power, reserved or otherwise, over the exercise of federal authority within its proper sphere.

Id. at 841 (Kennedy, J., concurring) (citation omitted) (quoting McCulloch v. Maryland, 17 U.S. (4 Wheat.) $316,430(1819)$ ). "The federal character of congressional elections flows from the political reality that our National Government is republican in form and that national citizenship has privileges and immunities protected from state abridgment by the force of the Constitution itself." Id. at 842. 
matters reserved to the States." 533 With this discussion, we see how Justice Harlan's views were quite ahead of his time, and how he foresaw monumental developments in the constitutional law of federalism far into the future.

\section{Congress Choosing Its Own Rules}

Harlan viewed the power of Congress to set its own rules as unchallengeable in court: "If the House of Representatives should by a resolution, however wrong, however against law, declare the seat of $\mathrm{A}$ vacant, that is the end of the matter. You cannot appeal to any power on the subject." ${ }_{334}$ The Warren Court later held to the contrary in Powell v. McCormack, ${ }^{535}$ finding that a virtually identical situation presented a justiciable issue. ${ }^{536}$

\section{Bicameralism and Presentment}

Harlan stressed the importance of bicameralism and presentment for a bill to become a law: "Is it a law when you show that alone [both houses concurred]? No. It shall be presented to the President of the United States. That is an essential prerequisite."537 This principle was only recognized, formally a century later in INS $v$. Chadha. ${ }^{538}$

\section{Appointment of Officers}

With respect to the Appointments Clause, Harlan took a rather formalist view: "Congress cannot create an ambassador, and say who shall fill it. The President has the appointment of all officers of the United States, with the single exception that he may invest the appointment of inferior officers in the heads of departments." 539 This view was arguably repudiated in Morrison $v$. Olson, ${ }^{540}$ however, in which the Court upheld Congress's scheme for court appointment of independent counsel..$^{541}$

$533 I d$. at 841 (citing United States v. Lopez, 514 U.S. 549 (1995)).

534 Justice Harlan's Lectures, supra note 1, at 67 (Lecture No. 6, Nov. 13, 1897).

535 Powell v. McCormack, 395 U.S. 486 (1969).

536 Id. at $547-48$.

537 Justice Harlan's Lectures, supra note 1, at 93 (Lecture No. 8, Dec. 4, 1897).

538 INS v. Chadha, 462 U.S. 919, 958-59 (1983) (holding unicameral legislative veto violated the separation of powers).

539 Justice Harlan's Lectures, supra note 1, at 225 (Lecture No. 18, Feb. 26, 1898).

540 Although the Court found the independent counsel to be an inferior officer, a substantial argument can be made that she was in fact a principal officer who should have been appointed by the President. Morrison v. Olson, 487 U.S. 654, 715-23 (1988) (Scalia, J., dissenting).

s41 Id. at 677. 


\section{CONCLUSION}

Today, John Marshall Harlan is widely considered one of the greatest Justices in the history of the Supreme Court. ${ }^{542}$ On the merits, his opinions often seem uncannily ahead of their time. Many of his majority opinions still hold, and his dissents were clarion calls for change, heeded by future generations. Somehow, Harlan alone divined how the Court would eventually interpret the Constitution. His lectures provide a portal back in time, showing how Harlan viewed the most controversial constitutional issues of his day and ours. His opinions in class, unlike the opinions on the Court, were unencumbered by the confines of building majorities, or by the constraints of stare decisis. What his students learned in class was the Constitution, according to John Marshall Harlan.

542 See Granite Valley Hotel Ltd. P'ship. v. Jackpot Junction Bingo \& Casino, 559 N.W.2d 135, 190 (Minn. Ct. App. 1997) ("It took 58 years to be persuasive, but his place in history is secure. We know his name. Without looking it up, name me all the majority writers in Plessy. Name me three? Name me one?"). 